\title{
F-Box Proteins and Cancer
}

\author{
Kanae Yumimoto, Yuhei Yamauchi and Keiichi I. Nakayama * $\mathbb{D}$ \\ Department of Molecular and Cellular Biology, Medical Institute of Bioregulation, Kyushu University, \\ 3-1-1 Maidashi, Higashi-ku, Fukuoka, Fukuoka 812-8582, Japan; tnkana@bioreg.kyushu-u.ac.jp (K.Y.); \\ yamauchi_yuhei3x@bioreg.kyushu-u.ac.jp (Y.Y.) \\ * Correspondence: nakayak1@bioreg.kyushu-u.ac.jp; Tel.: +81-92-642-6815
}

Received: 15 April 2020; Accepted: 12 May 2020; Published: 15 May 2020

\begin{abstract}
Controlled protein degradation is essential for the operation of a variety of cellular processes including cell division, growth, and differentiation. Identification of the relations between ubiquitin ligases and their substrates is key to understanding the molecular basis of cancer development and to the discovery of novel targets for cancer therapeutics. F-box proteins function as the substrate recognition subunits of S-phase kinase-associated protein 1 (SKP1)-Cullin1 (CUL1)-F-box protein (SCF) ubiquitin ligase complexes. Here, we summarize the roles of specific F-box proteins that have been shown to function as tumor promoters or suppressors. We also highlight proto-oncoproteins that are targeted for ubiquitylation by multiple F-box proteins, and discuss how these F-box proteins are deployed to regulate their cognate substrates in various situations.
\end{abstract}

Keywords: ubiquitin ligase; F-box protein; mutation; cancer

\section{Introduction}

Ubiquitylation-dependent proteasomal degradation of target proteins is an irreversible reaction that contributes to the regulation of many eukaryotic cellular processes-such as cell division, growth, and differentiation - at the level of selective protein turnover [1]. Impaired function of the ubiquitin-proteasome system often results in the aberrant stabilization of proto-oncogenic protein substrates that can eventually lead to carcinogenesis [2]. Conversely, abnormal up-regulation of the expression of certain ubiquitin ligases can result in the excessive degradation of tumor suppressor proteins and thereby also give rise to carcinogenesis. It is therefore important that the abundance of ubiquitin ligases that target promoters or suppressors of tumorigenesis be strictly controlled.

Ubiquitylation occurs via a sequence of enzymatic events in which the small protein ubiquitin is activated by linkage to an E1 (ubiquitin-activating) enzyme and is then transferred first to an E2 (ubiquitin-conjugating) enzyme and then to a free amine group either at the $\mathrm{NH}_{2}$-terminus or on an internal lysine residue of a substrate protein, with the transfer to the substrate being mediated by an E3 (ubiquitin ligase) enzyme. HECT (homologous to E6AP COOH-terminus)-type E3 enzymes catalyze ubiquitylation by first forming an E3-ubiquitin thioester intermediate, whereas RING (really interesting new gene) finger-, U box-, and plant homeodomain (PHD)-type E3s do not appear to form such an intermediate. In mammals, the largest family of E3 ubiquitin ligases consists of Cullin-RING ligases, of which SKP1-CUL1-F-box protein (SCF) complexes are the best characterized. Each SCF complex comprises SKP1 (S-phase kinase-associated protein 1), CUL1 (Cullin 1), RBX1 (RING-box protein 1; also known as ROC1, or regulator of Cullin 1), and one of a variety of F-box proteins [3]. F-box proteins are responsible for substrate recognition by each SCF complex, and they harbor two key functional domains: The F-box domain, which mediates association with the other components of the complex via direct interaction with SKP1, and the $\mathrm{COOH}$-terminal domain, which interacts with substrates [4]. On the basis of their different $\mathrm{COOH}$-terminal regions, F-box proteins are categorized 
into three classes: FBXW (containing a WD40-repeat domain), FBXL (containing a leucine-rich-repeat domain), and FBXO (containing another type of protein interaction domain or no recognizable domain) (Figure 1) [4]. Overexpression or mutations (deletions or point mutations) of certain F-box proteins have been associated with cancer progression [5]. In addition, mutations of the amino acid sequences of substrate proteins that are recognized by ubiquitin ligases, as well as perturbations that affect the posttranslational modification of such "degrons," may contribute to cancer development [6].

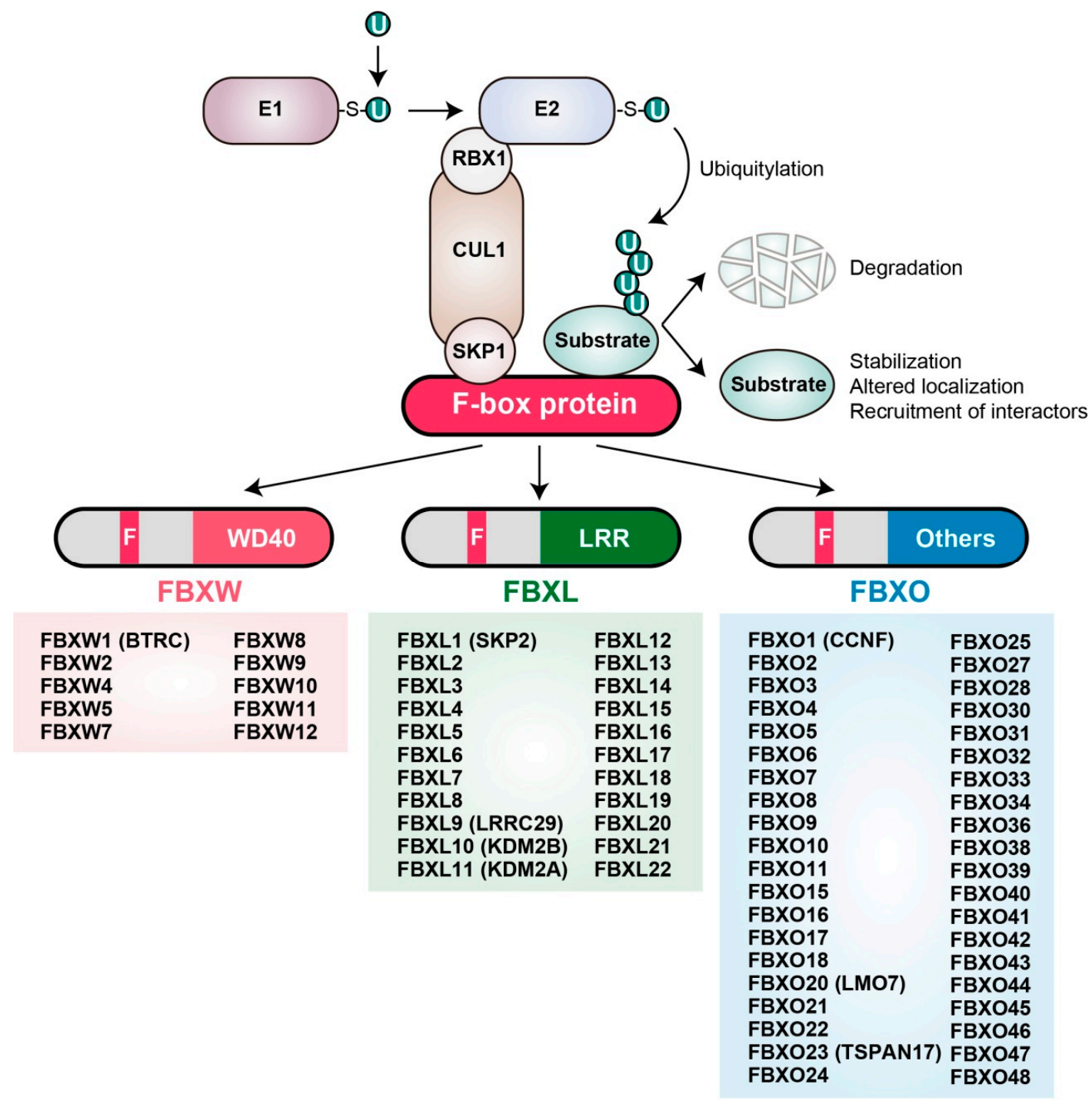

Figure 1. The S-phase kinase-associated protein 1 (SKP1)-Cullin1 (CUL1)-F-box protein (SCF) complex and its ubiquitylation of target proteins. The SCF complex functions together with E1 and E2 enzymes to mediate the ubiquitylation of target proteins. Each F-box protein binds to SKP1 via its F-box domain and to a substrate via its $\mathrm{COOH}$-terminal substrate interaction domain, thereby presenting the target protein for ubiquitylation. The SCF complex-mediated formation of a polyubiquitin chain on a substrate in most instances serves as a signal for proteasome-mediated degradation, although in some cases it instead leads to protein stabilization, a change in localization, or recruitment of other binding proteins (see Sections 2.2 and 3.1). F-box proteins fall into three major classes based on the type of substrate interaction domain: those that contain WD40 repeats (FBXW), leucine-rich repeats (FBXL), or other protein interaction domains (FBXO). Human F-box proteins in each class are shown. U, ubiquitin.

In this review, we summarize the oncogenic and oncosuppressive roles of specific F-box proteins. We also highlight proto-oncoproteins that are targeted for ubiquitylation by multiple F-box proteins 
as well as discuss how such F-box proteins are deployed to regulate such substrates in a manner dependent on the localization or function of the latter.

\section{Representative F-Box Proteins Related to Cancer}

\subsection{FBXO1 (Cyclin F)}

Cyclin F (FBXO1) was first identified in 1994 as the founding member of the F-box protein family [7]. It also belongs to the cyclin family of proteins and contributes to regulation of various cell cycle-related processes including centrosome duplication [8], maintenance of genome stability [9], and DNA replication and repair [10]. The amounts of cyclin F mRNA and protein oscillate during the cell cycle [7], with the amount of the mRNA increasing in $S$ phase, peaking in $G_{2}$ phase, and declining again in $\mathrm{M}$ phase. In contrast to other cyclins that cooperate with cyclin-dependent kinases (CDKs) to phosphorylate protein substrates and thereby control cell cycle events, cyclin F directly interacts with and mediates the ubiquitylation of its substrates in a manner independent of CDK activity $[8,10,11]$.

SCFCyclin F mediates the degradation of centrosomal protein of $110 \mathrm{kDa}(\mathrm{CP} 110)$, a promoter of centrosome duplication, a process that must occur only once during each cell cycle [8]. The timely degradation of $\mathrm{CP} 110$ controlled by $\mathrm{SCF}$ Cyclin $\mathrm{F}$ is therefore key to prevention of centrosome duplication more than once in the cell cycle. $\mathrm{SCF}^{\mathrm{Cyclin}} \mathrm{F}$ also targets cell division cycle 6 (CDC6), a protein that contributes to DNA replication, for ubiquitylation and subsequent degradation [9]. Such degradation of CDC6 prevents DNA re-replication or overreplication, which is highly disruptive to DNA integrity and increases the risk of genome instability. Another target of $\mathrm{SCF}^{\mathrm{Cyclin}} \mathrm{F}$ is stem-loop binding protein (SLBP), which contributes to the processing, translation, and degradation of mRNAs for canonical histones. The abundance of SLBP closely matches the demand for core histone proteins, and it declines

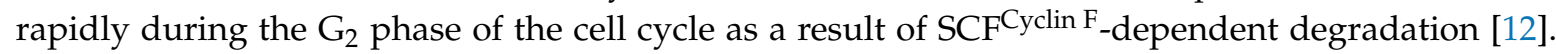
$\mathrm{SCF}$ Cyclin $\mathrm{F}$ controls assembly of the mitotic spindle by mediating degradation of nucleolar and spindle-associated protein 1 (NuSAP1), a protein that contributes to the organization of microtubules. In addition, degradation of the three activator E2F transcription factors (E2F1, E2F2, and E2F3A) in late $S$ and $G_{2}$ phases was recently shown to be mediated by $\operatorname{SCF} C y c l i n F[13,14]$. These various findings suggest that $S C F^{C y c l i n} \mathrm{~F}$ ensures accurate cell cycle progression in the $\mathrm{G}_{2}$ phase by targeting for degradation proteins that function in $\mathrm{S}$ phase.

Cyclin F also plays an important role in the cellular response to DNA damage. Cells depleted of cyclin $\mathrm{F}$ initiate checkpoint signaling after exposure to radiation, but they fail to maintain $\mathrm{G}_{2}$ arrest and progress prematurely into mitosis [11]. Moreover, SCF Cyclin F mediates the ubiquitylation of RRM2 [10], a subunit of ribonucleotide reductase, which catalyzes the conversion of ribonucleotides to deoxyribonucleotides. In response to the genotoxic induction of DNA damage, cyclin F is destabilized in a manner dependent on the protein kinase ATR, leading to RRM2 accumulation and deoxyribonucleotide production to facilitate DNA repair. In addition, cyclin F interacts with the transcription factor b-Myb via its cyclin-box domain and thereby suppresses cyclin A-mediated activation of b-Myb [11] in response to DNA damage signaling. Finally, $\mathrm{SCF}^{\mathrm{Cyclin} F}$ ubiquitylates exonuclease 1 and is thereby thought to prevent unnecessary DNA resection under stress conditions [15].

Given the characteristics of the substrates of SCF Cyclin F, cyclin F might be expected to serve as a tumor suppressor. Indeed, overexpression of cyclin $F$ in cultured cells was found to induce $G_{2}$ arrest and to prevent initiation of mitosis [7]. It has also been shown to limit centrosome duplication, with centrosome amplification being a hallmark of cancer. Furthermore, under conditions of metabolic stress, $\mathrm{SCF}^{\mathrm{Cyclin} \mathrm{F}}$ was found to be induced and to mediate polyubiquitylation of RBP-J $\mathrm{k}$, a mediator of Notch signaling, resulting in attenuation of the RBP-Jk-dependent oncogenic function of the R132H mutant of isocitrate dehydrogenase 1 (IDH1) [16]. Consistent with its expected role in tumor suppression, the expression of cyclin $\mathrm{F}$ has been found to be down-regulated in hepatocellular carcinoma, with the extent of this down-regulation correlating with a range of prognostic markers and having been proposed as a prognostic indicator in this disease [17]. 


\subsection{FBXL1 (SKP2)}

SKP2 (also known as FBXL1) was first identified as a protein associated with cyclin A [18]. It was subsequently shown to mediate the polyubiquitylation and consequent degradation of CDK inhibitors such as p27 ${ }^{K I P 1}$ [19-23], p57 ${ }^{K I P 2}$ [24], and p21 ${ }^{C I P 1}[25,26]$, and thereby to regulate the $\mathrm{G}_{1}-\mathrm{S}$ and $\mathrm{G}_{2}-\mathrm{M}$ transitions of the cell cycle [22,27]. Although mice deficient in SKP2 are viable, cells of the mutant animals contain markedly enlarged nuclei with polyploidy and multiple centrosomes as well as manifest a reduced growth rate and increased level of apoptosis [21]. These phenotypes are reversed by additional ablation of $\mathrm{p} 27^{\mathrm{KIP} 1}$, suggesting that this CDK inhibitor is the major substrate targeted by $\mathrm{SCF}^{\mathrm{SKP} 2}$ [22]. Several types of mutation and amplification of $S K P 2$ have been detected in various types of cancer, including cervical, endometrial, adrenocortical, ovarian, breast, and non-small-cell lung cancer [28]. Furthermore, the expression level of SKP2 is negatively associated with the survival of cancer patients-including those with prostate cancer [29], breast cancer [30,31], or lung cancer [32] - suggesting that SKP2 acts as an oncogene. Consistent with this latter notion, overexpression of SKP2 in mice promotes the development of prostate gland dysplasia [33] and $\mathrm{T}$ cell lymphoma [34], whereas ablation of $S k p 2$ impairs these processes [35,36]. Other cell cycle regulators-including p130 [37], Forkhead box protein O1 (FOXO1) [38], cyclin E [21], CDK9 [39], Recombination activating gene 2 (RAG2) [40], and b-Myb [41] - have also been identified as degradative substrates for $\mathrm{SCF}^{\mathrm{SKP} 2}$.

In addition to the proteolytic function of SKP2, recent studies have revealed that SKP2 exerts its oncogenic activity by mediating the conjugation of lysine-63 (K63)-linked polyubiquitin chains to target proteins such as protein kinase B (PKB; also known as AKT) [42], Yes-associated protein (YAP) [43], Twist transcriptional factor [44], Nijmegen breakage syndrome 1 (NBS1) [45], Ras related GTP binding A (RAG-A) [46], Breakpoint cluster region-Abelson (BCR-ABL) [47], human MutT homolog 1 (MTH1) [48], and Aurora-B [49], which results in the stabilization or alters the localization of these proteins or promotes the recruitment of interactors. The K63-linked ubiquitylation of the protein kinase AKT by SCF ${ }^{\text {SKP2 }}$ is stimulated by growth factors and cytokines, and it facilitates the recruitment of AKT to the plasma membrane, with its resulting hyperactivation leading to up-regulation of glycolysis and promotion of tumorigenesis [42,50]. A recent study also indicates that $\mathrm{SCF}^{\mathrm{SKP} 2}$-mediated AKT ubiquitylation contributes to chemoresistance of cancer cells [51]. The phosphatidylinositol 3-kinase (PI3K) inhibitor Buparlisib (BKM-120) was thus shown to promote SCF $^{\text {SKP2 }}$-mediated ubiquitylation and reactivation of AKT in a subset of triple-negative breast cancer cell lines, and depletion of SKP2 attenuated the growth of such cells that were resistant to BKM-120. K63-linked ubiquitylation of the transcription factor YAP by SCF ${ }^{\mathrm{SKP} 2}$ promotes its nuclear localization in a manner independent of Hippo signaling and thereby enhances its transcriptional activity and growth-promoting function [43]. YAP, in turn, promotes the p300-mediated acetylation and cytoplasmic retention of SKP2, resulting in excessive degradation of the pro-apoptotic factors FOXO1 and FOXO3, the development of polyploidy and genomic instability, and oncogenesis [52]. These findings raise the possibility that SKP2 and YAP each reciprocally enhance the oncogenic function of the other.

Given the roles of SKP2 in carcinogenesis and cancer progression, inactivation of SKP2 is a potentially promising approach to cancer treatment. Several inhibitors of SKP2 have been developed [53]. Compound 25 (also known as SZL-P1-41), for example, disrupts the interaction between SKP2 and SKP1 and thereby promotes disassembly of the SCF ${ }^{S K P 2}$ complex [54], whereas compound A (also known as CdpA) disrupts the interaction between SKP2 and p27 KIP1 [55]. Some agents target the interaction between SKP2 and the protein CDK subunit 1 (CKS1), which is essential for the recognition of p27 KIP1 by SKP2 [56-58]. A compound known as Dioscin was recently shown to attenuate SKP2 expression [59], in part by enhancing the interaction between SKP2 and Fizzy-related, Hct1 homolog (CDH1), a cofactor of APC/C (anaphase-promoting complex/cyclosome) that mediates the ubiquitylation and degradation of SKP2 $[60,61]$. Further investigation is required to determine whether these various inhibitors are effective in cancer treatment. 


\subsection{FBXW7}

F-box/WD repeat-containing protein 7 (FBXW7; also known as Fbw7, SEL-10, hCDC4, or hAgo) was first discovered as a negative regulator of the LIN-12 (Notch) signaling pathway in Caenorhabditis elegans by genetic screening [62]. It was later shown to negatively regulate cell cycle progression, stem cell maintenance, and differentiation of multiple cell types by mediating the degradation of various substrates in a phosphorylation-dependent manner [63-65]. FBXW7 recognizes a conserved phosphorylation motif known as the Cdc4 phosphodegron (CPD), which typically consists of $\phi X \phi \phi \phi(\mathrm{T} / \mathrm{S}) \mathrm{PPX}(\mathrm{T} / \mathrm{S} / \mathrm{D} / \mathrm{E})$ (where $\phi$ represents a hydrophobic amino acid) [66]. About 90 proteins have been identified to date as substrates of FBXW7 [67], many of which are proto-oncoproteins including a transcription factor c-Myc [68,69], a transmembrane receptor Notch [62,70,71], a transcription factor c-Jun [72,73], cyclin E [74-76], Krüppel-like factor 5 (KLF5) [77,78], and Myeloid cell leukemia 1 (MCL1) $[79,80]$.

Among the $\sim 70$ F-box protein genes identified in humans, FBXW7 has the highest mutation frequency in cancer [67], indicative of the importance of the encoded protein as a tumor suppressor in cancer development. Cancer-associated FBXW7 mutations are most frequent in T cell acute lymphoblastic leukemia (T-ALL), followed by precursor T cell lymphoblastic lymphoma (T-LBL), endometrial carcinoma, small intestine carcinoma, and large intestine carcinoma. Such mutations of FBXW7 are concentrated in the codons for three arginine residues ( $\mathrm{Arg}^{465}, \mathrm{Arg}^{479}$, and $\mathrm{Arg}^{505}$ ) in the WD40-repeat domain responsible for substrate binding. These arginine residues form a positively charged pocket at the inner rim of the $\beta$-propeller channel of the protein, and they form charge-stabilized hydrogen bonds with the substrate by enveloping the negatively charged phosphate group at the " 0 " position of the CPD $[66,81]$.

In addition to loss-of-function mutations in the substrate binding domain of FBXW7, mutations of FBXW7 substrates have been found to be associated with cancer and to concentrate in the CPD. Activating mutations of NOTCH1 have thus been identified in 50\% to $60 \%$ of T-ALL [82] and precursor T-LBL $[83,84]$ cases, and $~ 10 \%$ of these mutations affect the codon for Pro ${ }^{2514}$ in the CPD of the encoded protein and are predicted to abrogate the interaction with FBXW7. In addition, in $\sim 43 \%$ of individuals with diffuse large B cell lymphoma (DLBCL) positive for nonsense or missense mutations of $M Y C$, the mutations are located in the CPD sequence [67], suggesting that impaired degradation of c-Myc by FBXW7 is a key mechanism underlying c-Myc accumulation in DLBCL. KLF5, another substrate of FBXW7, is necessary for the initial steps of tumor development in $A p c^{\mathrm{Min}}$ and $A p c^{\mathrm{Min}} \mathrm{KR} A S^{\mathrm{G} 12 \mathrm{~V}}$ mouse models of colorectal cancer $[85,86]$, and a large proportion of the mutations of KLF5 in cancer patients are concentrated in its CPD [67].

Certain small compounds have been found to activate $\mathrm{SCF}^{\mathrm{FBXW7}}$ directly or indirectly. Oridonin increases the expression of FBXW7 and also activates glycogen synthase kinase-3 (GSK-3), which mediates the phosphorylation of c-Myc and thereby promotes its turnover, in leukemia and lymphoma cells [87]. SINE KPT-185, an inhibitor of exportin 1, blocks the nuclear export of FBXW7 and thereby promotes degradation of Notch1 in the nucleus of pancreatic cancer cells [88]. Genistein down-regulates expression of the microRNA miR-223, resulting in up-regulation of FBXW7 expression, inhibition of cell growth and invasion, and induction of apoptosis in pancreatic cancer cells [89].

Although most research on the role of FBXW7 in cancer has focused on its tumor suppressor function in cancer cells themselves, FBXW7 also suppresses cancer metastasis by inhibiting cancer niche formation by noncancer cells [90]. Ablation of $\mathrm{Fbxw7} 7$ in mouse bone marrow-derived stromal cells was thus found to promote metastatic tumor growth in a manner dependent on Notch1 accumulation and activation of $\mathrm{C} / 2$ transcription. Increased circulating levels of the chemokine CCL2 in the FBXW7-deficient mice supported the recruitment of both monocytic myeloid-derived suppressor cells and macrophages to establish the cancer niche. Consistent with these findings in mice, low FBXW7 expression levels in peripheral blood cells are associated with poor prognosis in human breast cancer patients [90]. 


\subsection{FBXW1 $(\beta-\operatorname{Tr} C P 1)$ and $F B X W 11(\beta-\operatorname{Tr} C P 2)$}

Human $\beta$-transducin repeat containing protein $(\beta-\operatorname{TrCP})$, which includes both $\beta$-TrCP1 (FBXW1) and $\beta-\operatorname{TrCP} 2$ (FBXW11), was originally identified as a cellular ubiquitin ligase that is bound by the HIV-1 protein Vpu and thereby directed to eliminate cellular CD4 by targeting it for proteolysis [91]. Subsequently, $\beta$-TrCP was shown to regulate multiple cellular processes by mediating the degradation of various substrates in a phosphorylation-dependent manner [5]. The WD40-repeat motif of $\beta$-TrCP recognizes a $\mathrm{DSGX}_{n} \mathrm{~S}$ (where $\mathrm{X}$ is any amino acid) destruction motif (or variants thereof) of target proteins in which the serine residues are phosphorylated by specific kinases. Several proteins including the transcriptional coactivator $\beta$-catenin [92-95], Nuclear factor-kB (NF-kB; p105 and p100), Inhibitor

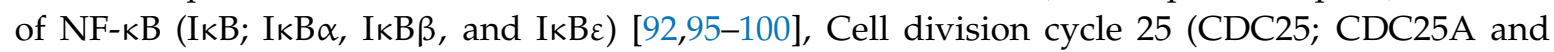
CDC25B) [101-104], Mitosis inhibitor protein kinase WEE1 [105], and Snail zinc-finger transcription factors $[106,107]$ have been implicated as substrates of $\beta$-TrCP.

Given the diversity of its substrates, $\beta$-TrCP might be expected to play both oncogenic and tumor-suppressive roles in a context-dependent manner. Some studies have suggested that $\beta$ - $\operatorname{TrCP}$ primarily plays an oncogenic role by mediating the degradation of tumor suppressors including IкB [92,95-100], FOXO3 [108], REST [109], and PDCD4 [110]. Indeed, $\beta-\operatorname{TrCP1}$ is overexpressed in various types of cancer including colorectal cancer [111], pancreatic cancer [112], melanoma [113], and hepatoblastoma [114] in a manner independent of $\beta$-catenin mutational status. Tissue-specific overexpression of exogenous $\beta$-TrCP1 in mouse mammary gland and other epithelial tissues was shown to promote cell proliferation [115] and to give rise to corresponding carcinomas including mammary, ovarian, and uterine tumors. However, mice transgenic for a dominant negative form of $\beta$-TrCP1 lacking the F-box domain were found to develop intestinal adenomas as well as hepatic and urothelial tumors [116], suggestive of an oncosuppressive function of $\beta$ - $\operatorname{TrCP}$.

The best-characterized cancer-suppressing function of $\beta-\operatorname{TrCP}$ relates to the degradation of $\beta$-catenin, a key molecule in the canonical Wnt signaling pathway. The constitutive activation of this pathway is thought to be the initiating event in colorectal cancer, with such activation occurring mainly as a result of mutation of APC (adenomatous polyposis coli gene) and consequent inhibition of GSK- $3 \beta$-dependent phosphorylation of the $\beta$-catenin phosphodegron. Missense mutations of the $\beta$-catenin phosphodegron (affecting residues Asp ${ }^{32}, \mathrm{Ser}^{33}, \mathrm{Gly}^{34}, \mathrm{Ser}^{37}, \mathrm{Thr}^{41}$ and $\mathrm{Ser}^{45}$ ) have been identified in some individuals with tumors harboring wild-type alleles of APC (Figure 2A), with these mutations resulting in the abnormal stabilization of $\beta$-catenin and Wnt pathway activation. Such phosphodegron mutations of $\beta$-catenin have also been detected in endometrial cancer, hepatobiliary cancer, liver cancer, and melanoma [117]. In-frame deletions spanning exon 3 of the $\beta$-catenin gene (CTNNB1), which encodes the phosphodegron, were recently identified in metastatic colorectal cancer, with nuclear staining of $\beta$-catenin being apparent in such tumors [118].

SETBP1 is another substrate of $\beta-\operatorname{TrCP}$ in which cancer-associated mutations are concentrated in the phosphodegron for $\mathrm{SCF}^{\beta-\operatorname{TrCP}}$-dependent degradation (Figure 2B). SETBP1 was first identified as a protein that binds to the acute undifferentiated leukemia-associated protein SET, which inhibits the activity of protein phosphatase 2A [119], and it was subsequently found to function as a transcription factor that increases the expression of HOXA9, HOXA10 [120], and b-Myb [121] genes as well as represses that of the RUNX1 gene [122]. Somatic mutations of SETBP1 have been identified in several myelodysplastic/myeloproliferative neoplasms, including atypical chronic myeloid leukemia [123], chronic myelomonocytic leukemia [124], juvenile myelomonocytic leukemia [125], and secondary acute myeloid leukemia [124], but not in lymphoblastic leukemia or solid tumors. Consistent with these clinical observations, transplantation experiments in mouse models revealed the biological relevance of mutated SETBP1 to myeloid leukemogenesis [124]. 


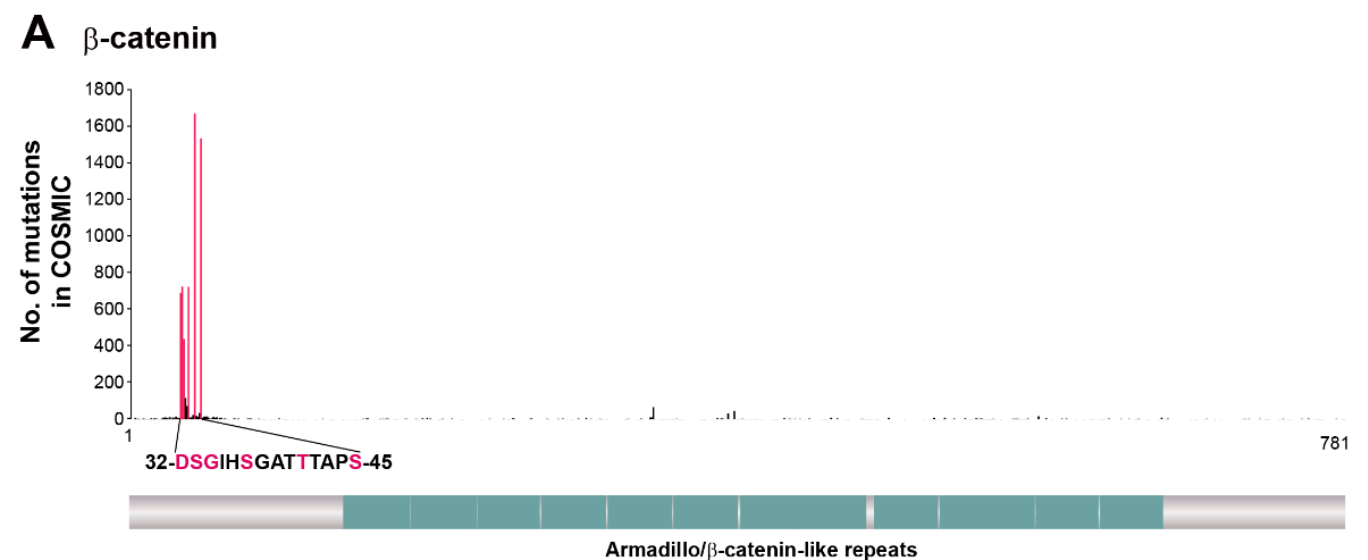

B SETBP1

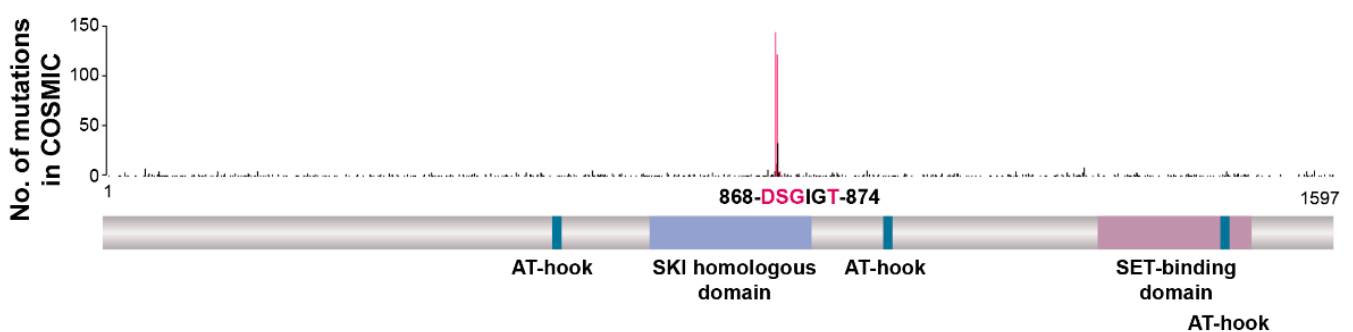

Figure 2. Distribution along the encoded protein sequences of CTNNB1 ( $\beta$-catenin gene) and SETBP1 mutations identified in the genomes of cancer patients. The numbers of CTNNB1 (A) and SETBP1 (B) genetic alterations were obtained from the COSMIC database (version 90). Mutations corresponding to the consensus sequence of the phosphodegron for $\beta-\operatorname{TrCP}$ are shown in pink.

Although several drugs have been found to inhibit or upregulate $\beta$-TrCP, such inhibition in the clinical setting is likely to be associated with side effects, given that the substrates of $\beta$-TrCP include both tumor promoters and tumor suppressors. Indeed, treatment with the $\beta-\operatorname{TrCP}$ inhibitor erioflorin resulted in the accumulation of $\beta$-catenin, IKB $\alpha$, and PDCD4 in HEK293T cells, suggesting that erioflorin stabilizes various $\beta$-TrCP targets [126]. Another $\beta$-TrCP-targeting agent, STG28, increases the abundance of $\beta$-TrCP and thereby reduces that of multiple $\beta$-TrCP substrates including $\beta$-catenin, I $\mathrm{B} \alpha, \mathrm{WEE} 1, \mathrm{CDC} 25 \mathrm{~A}$, and NF- $\mathrm{BB}$ (p105) [127]. However, GS143 specifically inhibits the interaction between $\beta-\operatorname{Tr} C P$ and phosphorylated $\operatorname{I\kappa } B \alpha$ and thereby attenuates the ubiquitylation of $\operatorname{I\kappa } B \alpha$, without affecting that of $\beta$-catenin [128]. Inhibitors such as GS143 that target specific substrates are more likely to have therapeutic applications.

\subsection{FBXL5}

Although iron is an essential micronutrient in cells and organisms, it can be toxic to cells if present in excess. It is therefore important that cellular iron levels be subject to strict regulation. FBXL5 is an important E3 ligase with regard to the regulation of iron metabolism $[129,130]$. The $\mathrm{NH}_{2}$-terminal region of FBXL5 contains a hemerythrin (Hr)-like domain that functions as a sensor for cellular iron. In the presence of iron, this domain forms a compact tertiary structure that is resistant to limited proteolysis and masks a degron composed of residues 77 to 81 within the $\mathrm{Hr}$ domain, resulting in the accumulation of FBXL5. When iron is limiting, however, the compact structure of the Hr domain is compromised and the degron becomes accessible to an as yet unidentified E3 ubiquitin ligase that mediates the polyubiquitylation of FBXL5 [131]. Various proteins including Dynactin subunit p150 Glued [132], Iron-regulatory protein 1 (IRP1) [130], IRP2 [129,130], Snail [133], Single-stranded 
DNA-binding protein 1 (SSB1) [134], and CBP/p300-interacting-transactivator-with-an ED-rich-tail 2 (CITED2) [135] have been identified as substrates of SCF ${ }^{\mathrm{FBXL} 5}$.

Mice deficient in FBXL5 die in utero as a result of excessive iron accumulation [136]. This embryonic mortality was prevented by additional ablation of the FBXL5 substrate IRP2 (iron regulatory protein 2), suggesting that impaired degradation of IRP2 is primarily responsible for the death of FBXL5-deficient mice. Deletion of Fbxl5 specifically in the hematopoietic system of mice resulted in cellular iron overload in hematopoietic stem cells and impaired the ability of these cells to repopulate bone marrow as a result of abnormal activation of both oxidative stress responses and the cell cycle [137]. Liver-specific deletion of Fbxl5 resulted in dysregulation of both hepatic and systemic iron homeostasis, leading to the development of steatohepatitis. FBXL5 deficiency in the liver promoted chemical carcinogen-induced hepatocarcinogenesis as a result of excessive iron accumulation followed by oxidative stress, tissue damage, inflammation, and compensatory proliferation of hepatocytes [138]. Consistent with these observations in mice, down-regulation of FBXL5 expression was found to be associated with poor prognosis in patients with hepatocellular carcinoma. The abundance of FBXL5 mRNA was also found to be reduced in the liver of patients with chronic hepatitis C virus (HCV) infection [139], and FBXL5 deficiency promotes carcinogenesis induced by the HCV core protein [138].

FBXL5 inhibits epithelial-to-mesenchymal transition (EMT) and attenuates metastasis by targeting the transcription factor Snail in gastric cancer [133,140]. It also attenuates cisplatin resistance induced by RhoGDI2 (a guanine nucleotide dissociation inhibitor for Rho-family GTPases) in gastric cancer cells [141]. In contrast to its tumor suppressor function in the liver and stomach, FBXL5 promotes colon cancer progression through regulation of the PTEN-PI3K-AKT signaling pathway [142]. FBXL5 is highly expressed in colon cancer, and its high expression has been associated with reduced overall survival and exaggerated clinicopathologic characteristics in colon cancer patients. AM404, a metabolite of acetaminophen with antibacterial activity, was found to suppress the expression of FBXL5 and to inhibit the dedifferentiation and acquisition of stem-like properties in organoids of colon cancer patients, suggesting that this agent might have potential as an anticancer drug [143]. It thus appears that FBXL5 positively or negatively regulates carcinogenesis in a tissue-dependent manner.

\section{Tumor Promoters Regulated by Multiple F-Box Proteins}

\section{1. $c-M y c$}

c-Myc was identified as a cellular counterpart of the v-Myc protein of avian leukemia virus. Translocation of the c-Myc gene $(M Y C)$ is a cause of Burkitt's lymphoma, and the gene has long been known to play a major role in tumorigenesis. c-Myc functions as a transcription factor in association with its primary partner MAX, its interaction with which is mediated by its $\mathrm{COOH}$-terminal basic helix-loop-helix/leucine zipper (bHLH/LZ) domain. Many target genes are transcriptionally activated as a result of the association of the c-Myc/MAX heterodimer with canonical E-box (CACGTG) elements within their promoter or enhancer regions. c-Myc coordinately regulates the expression of a large number of genes implicated in diverse cellular processes, including cell cycle progression, metabolism, nucleotide biosynthesis, RNA processing, translation, cell differentiation, cell senescence, and apoptosis. It is therefore not surprising that the level and activity of c-Myc are strictly regulated at the transcriptional, translational, and posttranslational levels. In particular, ubiquitylation-dependent protein degradation plays a central role in the regulation of c-Myc abundance, with the loss of such regulation leading to cancer progression.

The most frequent MYC mutations associated with cancer are located in the codons for $\mathrm{Thr}^{58}$ and $\mathrm{Pro}^{59}$ in the $\mathrm{NH}_{2}$-terminal transactivation domain, with such mutations having been shown to stabilize c-Myc by preventing its degradation by the ubiquitin-proteasome system (Figure 3A). Indeed, mice transgenic for the c-Myc(T58A) mutant show a higher penetrance and reduced latency of cancer development compared with those transgenic for the wild-type protein $[144,145]$. This region of c-Myc has been shown to be recognized by three F-box proteins-FBXW7, FBXL3, and FBXL14 (Figure 3A)—with SCF ${ }^{\mathrm{FBXW7}}$ being 
the best characterized ubiquitin ligase for c-Myc degradation [68,69]. Both $\mathrm{Thr}^{58}$ and $\mathrm{Pro}^{59}$ of c-Myc are critical residues of the FBXW7 recognition motif (CPD), and phosphorylation of Thr ${ }^{58}$ by GSK-3 $\beta$ is essential for the interaction of c-Myc with FBXW7 and its subsequent degradation. Conditional deletion of Fbxw7 in mouse thymus results in excessive accumulation of c-Myc, giving rise to marked thymic hyperplasia followed by the spontaneous development of thymic lymphoma [146]. FBXW7-mediated c-Myc degradation is also important for the maintenance of cell stemness, at least in hematopoietic stem cells [147-150], keratinocytes [151], and cancer stem cells [152,153].

A

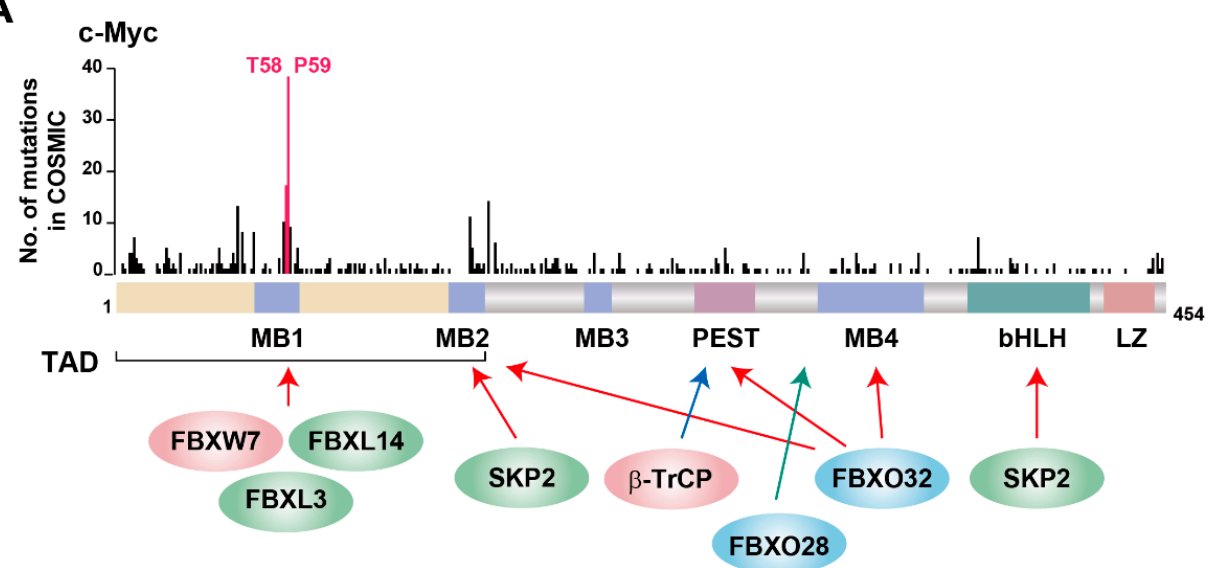

B

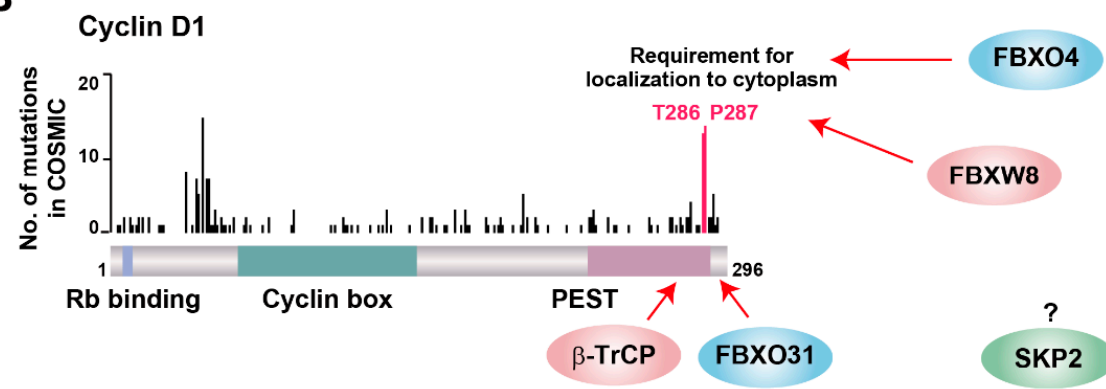

C

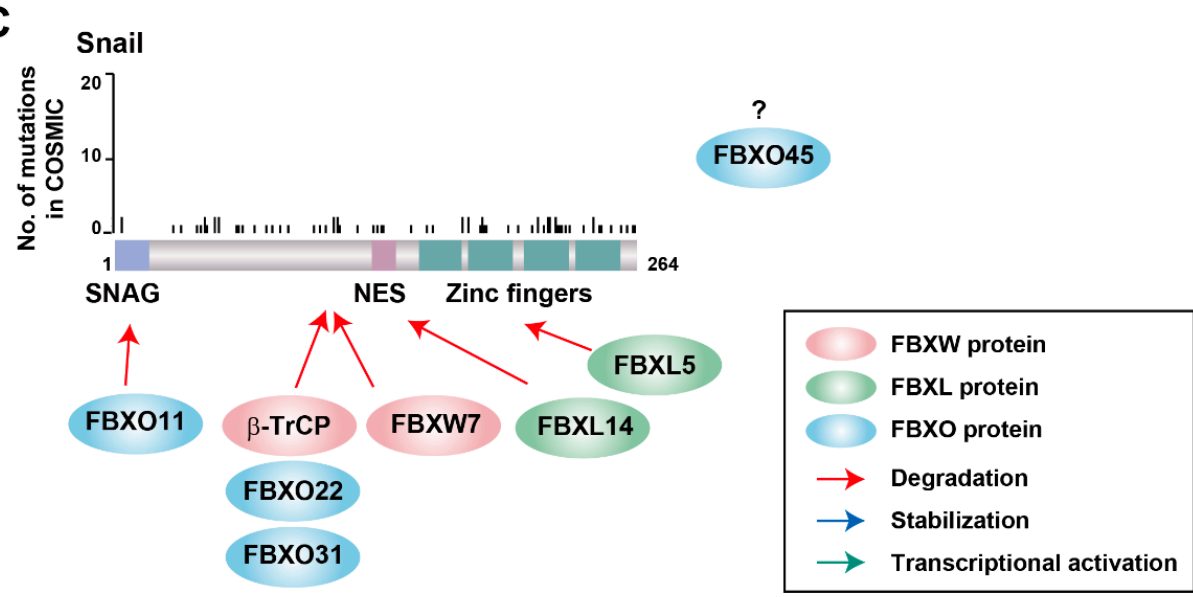

Figure 3. Distribution along the encoded protein sequences of $M Y C, C C N D 1$, and SNAI1 mutations identified in the genomes of cancer patients. The numbers of MYC (A), CCND1 (B), and SNAI1 (C) genetic alterations were obtained from the COSMIC database (version 90). Mutations corresponding to critical amino acids for the half-life of c-Myc (A) or cyclin D1 (B) are shown in pink. Arrows show the recognition sites for F-box proteins and their cofactors. 
FBXL3 is another F-box protein that targets the $\mathrm{Thr}^{58}$-phosphorylated form of c-Myc for ubiquitylation [154]. $\mathrm{SCF}^{\mathrm{FBXL3}}$ was originally identified as a ubiquitin ligase for the circadian clock components CRY1 and CRY2 that functions in a clock-dependent manner [155-157]. CRY2, but not CRY1, was shown to cooperate with FBXL3 to affect the degradation of c-Myc in a Thr ${ }^{58}$ phosphorylation-dependent manner [154]. This unexpected function of CRY2 may contribute to circadian protection from tumorigenesis. FBXL14 also targets $\mathrm{Thr}^{58}$-phosphorylated c-Myc for ubiquitylation [158]. FBXL14 is preferentially expressed in non-stem- like glioma cells and neural progenitors, whereas it is expressed at only a low level in glioma stem cells that contribute to tumor initiation and malignant progression. Overexpression of FBXL14 induces the differentiation of and inhibits tumor formation by glioma stem cells, with these effects being reversed by expression of the c-Myc(T58A) mutant.

c-Myc has also been shown to be ubiquitylated in a manner independent of $\mathrm{Thr}^{58}$ phosphorylation. $\mathrm{SCF}^{\mathrm{FBXO} 2}$ targets c-Myc for proteasomal degradation by mediating its ubiquitylation at $\mathrm{Lys}^{326}$ via K48-linked ubiquitin chains [159]. FBXO32 interacts with c-Myc at its Myc-box (MB) 2, MB4, and PEST (rich in proline, glutamic acid, serine, and threonine) domains. Of note, FBXO32 is a target gene of c-Myc, with FBXO32 and c-Myc thus contributing to a negative regulatory loop for the control of c-Myc function. FBXO28 is another F-box protein that interacts with and thereby mediates the ubiquitylation of c-Myc in a $\mathrm{Th}^{58}$ phosphorylation-independent manner [160]. SCF ${ }^{\mathrm{FBXO} 28}$ mediates nonproteolytic ubiquitylation of c-Myc that promotes recruitment of the p300 histone acetyltransferase by c-Myc located at the promoters of its target genes. SKP2 also binds to the MB2 and bHLH/LZ domains of c-Myc associated with chromatin, which initially increases the transactivation activity of c-Myc but later results in its ubiquitylation and degradation during the $\mathrm{G}_{1}-\mathrm{S}$ transition of the cell cycle [161,162]. The SKP2-mediated activation of c-Myc is independent of c-Myc ubiquitylation, given that a SKP2 mutant that is unable to form an SCF complex also manifested this effect $[163,164]$.

Although $\mathrm{SCF}^{\beta-\mathrm{TrCP}}$ also ubiquitylates c-Myc in a manner dependent on its phosphorylation by Polo-like kinase 1 (PLK1), it forms a heterotypic K33/K48/K63 polyubiquitin chain on c-Myc instead of a monotypic K48-linked one [165]. This heterotypic polyubiquitin chain serves as a signal not for translocation to the proteasome but rather for the stabilization of c-Myc. Given that $\mathrm{SCF}^{\beta-\mathrm{TrCP}}$ ubiquitylates the same amino acid residues of $\mathrm{c}-\mathrm{Myc}$ as does $\mathrm{SCF}^{\mathrm{FBXW7}}$, competition between these two F-box proteins contributes to the strict regulation of c-Myc abundance. Many other types of ubiquitin ligase including Cullin-RING ligase 3/speckle-type POZ protein (CRL3 ${ }^{\text {SPOP }}$ ), Cullin-RING ligase 4/tumor necrosis factor receptor-associated ubiquitous scaffolding and signaling protein (CRL4 ${ }^{\text {TRUSS }}$ ), Tripartite motif protein (TRIM32), Ring finger protein 12 (also known as RLIM), p53-induced RING H2 protein (PIRH2), HECT, UBA and WWE domain containing E3 ubiquitin protein ligase 1 (HUWE1, also known as ARF-BP1), the carboxyl terminus of Hsp70-interacting protein (CHIP), and eleven-nineteen lysine-rich leukaemia (ELL) have also been shown to mediate c-Myc ubiquitylation [166].

\subsection{Cyclin D1}

Human cyclin D1 was first discovered through screening of a cDNA expression library constructed from a glioblastoma cell line for the ability to complement the growth of conditional $\mathrm{G}_{1}$ cyclin-defective yeast strains [167]. D-type cyclins-including cyclins D1, D2, and D3-form active complexes with CDK4 or CDK6 that phosphorylate retinoblastoma protein $(\mathrm{Rb})$ and promote $\mathrm{G}_{1}$-to-S phase progression [168]. They coordinate cell cycle progression with extracellular stimuli such as those related to growth factor or nutrient availability and integrin-mediated adhesion signaling [169]. Given this role of D-type cyclins, it is not surprising that their overexpression or overactivation of their cognate CDKs directly contributes to tumor growth. Indeed, the CCND1 gene is amplified in a variety of human cancers [170].

Cyclin D1 is highly unstable, with a half-life of 10 to $30 \mathrm{~min}$, and its degradation depends on the stage of the cell cycle $[171,172]$. The most frequently mutated codons of CCND1 include those for $\mathrm{Thr}^{286}$ 
and $\mathrm{Pro}^{287}$ in the $\mathrm{COOH}$-terminal region of the encoded protein (Figure 3B), with mutations affecting $\mathrm{Thr}^{286}$ resulting in stabilization and persistent nuclear localization of cyclin D1 [173]. Phosphorylation of $\mathrm{Thr}^{286}$ occurs during the $\mathrm{G}_{1}-\mathrm{S}$ transition and directs the CRM1-mediated export of cyclin D1 from the nucleus to the cytoplasm, where it is subjected to ubiquitylation and proteasomal degradation $[171,174]$. Such phosphorylation of cyclin D1 was shown to be required for ubiquitylation by four cytosolic F-box proteins: FBXO4, FBXO31, $\beta$-TrCP, and FBXW8. The interaction between FBXO4 and cyclin $\mathrm{D} 1$ in the cytoplasm depends mainly on the presence of $\alpha \mathrm{B}$-crystallin, which belongs to the small heat shock protein family and functions as a molecular chaperone [175]. Fbxo4 $4^{-/}$or $\mathrm{FbxO}^{4^{+-}}$ mice spontaneously develop multiple tumors-including lymphoma, histiocytic sarcoma, and, less frequently, mammary and hepatocellular carcinomas [176] — as well as show an increased susceptibility to the $N$-nitrosomethylbenzylamine-induced development of papilloma [177]. Loss of Fbxo4 also increases the aggressiveness of $B R A F^{\mathrm{V} 600 \mathrm{E}}$-dependent metastatic melanoma in mice [178], highlighting the importance of $\mathrm{FBXO} 4$ as a suppressor of tumor progression.

Whereas FBXO4 is thought to contribute to the normal cell cycle-dependent oscillation of cyclin D1, FBXO31 is a checkpoint protein induced by DNA damage that promotes cyclin D1 degradation and subsequent $G_{1}$ arrest of the cell cycle in response to genotoxic stress [179]. The interaction of cyclin D1 with FBXO31 in vitro is independent of the phosphorylation of $\mathrm{Thr}^{286}$, but it requires the COOH-terminal region (residues 287-295) of cyclin D1 [180]. Biochemical analyses revealed that FBXO31 directly interacts with cyclin D1, ubiquitylates it, and targets it to the proteasome for degradation in a $\mathrm{Thr}^{286}$ phosphorylation-dependent manner in cells, however, suggesting that the nuclear export of cyclin D1 is important for $\mathrm{SCF}^{\mathrm{FBXO} 31}$-mediated ubiquitylation.

$\beta$-TrCP-mediated cyclin D1 ubiquitylation and degradation were discovered in cells treated with STG28, a derivative of troglitazone, as a result of the finding that the glitazone family of peroxisome proliferator-activated receptor $\gamma(\operatorname{PPAR} \gamma)$ agonists induces PPAR $\gamma$-independent degradation of cyclin D1 [181]. STG28 up-regulates $\beta$-TrCP expression, with the interaction of cyclin D1 and $\beta-\operatorname{TrCP}$ being promoted in STG28-treated cells. Cyclin D1 contains an unconventional recognition sequence (279-EEVDLACpT-286) for $\beta$-TrCP, with $\mathrm{Glu}^{280}$ serving as a phosphomimetic residue in place of the upstream phosphoserine. FBXW8 also ubiquitylates cyclin D1 in a Thr ${ }^{286}$ phosphorylation-dependent manner, with depletion of FBXW8 inducing marked accumulation of cyclin D1 [182]. Although SKP2 has been implicated in the regulation of cyclin D1 abundance [25], ubiquitylation of cyclin D1 by $\mathrm{SCF}^{\mathrm{SKP} 2}$ has not been demonstrated, suggesting that this regulation may be indirect. In addition to F-box proteins, APC/C has been shown to mediate cyclin D1 ubiquitylation [183].

Generation of $\mathrm{FbxO4}^{-/-}$, $\mathrm{Fbxw8}^{-/-}$, and $\mathrm{FbxO4}^{-/-} \mathrm{Fbxw8} 8^{-/-}$mice in an investigation into which F-box proteins are most relevant to cyclin D1 degradation revealed that the stability of cyclin D1 was unchanged

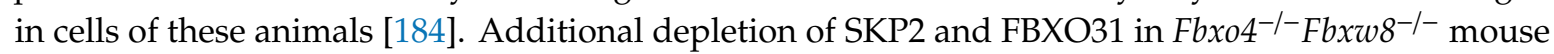
embryonic fibroblasts also did not affect the half-life of cyclin D1, and interaction of cyclin D1 with either FBXO4, FBXW8, FBXO31, SKP2, or $\beta$-TrCP1 was not detected in NIH 3T3 cells. Furthermore, abrogation of the function of SCF or APC/C complexes by expression of a dominant negative mutant of CUL1 or depletion of APC2, respectively, had no effect on the half-life of cyclin D1. Together, these results suggested that the examined F-box proteins are all dispensable for cyclin D1 degradation, at least during normal progression of the cell cycle, and they thus implicated the existence of an unidentified ubiquitin ligase for cyclin D1.

\subsection{Snail}

Snail (SNAI1) was first identified in Drosophila melanogaster as a factor essential for mesoderm formation $[185,186]$ and was later shown to contribute to EMT, which plays a key role in the progression and metastasis of epithelial tumors. Snail interacts with genomic DNA containing E-box sequence motifs via its $\mathrm{COOH}$-terminal zinc-finger domain as well as with the histone deacetylases HDAC1 and HDAC2 via its $\mathrm{NH}_{2}$-terminal SNAG domain $[187,188]$. It acts as a transcriptional repressor-both by inducing the removal of transcriptional activators from its binding sites and by promoting histone 
deacetylation-at target genes such as that for E-cadherin, a marker of EMT. Expression of SNAI1 is positively associated with tumor grade, recurrence, and metastasis as well as with poor prognosis in individuals with various tumor types [189].

Snail is highly unstable, with a half-life of $25 \mathrm{~min}$ in human cells [106]. Many F-box proteins ( $\beta$-TrCP, FBXO31, FBXO22, FBXL14, FBXL5, FBXW7, FBXO11, and FBXO45) have been implicated in EMT on the basis of their relation to the degradation of Snail (Figure 3C). Snail is one of the best characterized targets of $\mathrm{SCF}^{\beta-\operatorname{TrCP}}[106,107]$, with its phosphorylation at $\operatorname{Ser}^{104}$ and $\mathrm{Ser}^{107}$ promoting its localization to the cytoplasm, where its DSG phosphodegron motif (95-DpSGKGpS-100) is recognized by $\beta$ - $\operatorname{TrCP}[106,190]$. Phosphorylation of the Ser ${ }^{104}$ residue in the nucleus primes further cytosolic phosphorylation at Ser $^{96}$ and Ser ${ }^{100}$ by GSK-3 $\beta$, which facilitates recognition by $\beta$-TrCP. Phosphorylation at these sites is also required for FBXO31- and FBXO22-dependent ubiquitylation and degradation of Snail in gastric [191] and breast [192] cancer, respectively. Snail binds to the F-box domain of FBXO31 [191], however, is suggestive of SCF complex-independent ubiquitylation by FBXO31. Phosphorylation of Snail at Thr ${ }^{203}$ by LATS2 [193], at $\operatorname{Ser}^{246}$ by PAK1 [194], or at Ser ${ }^{82}$ and Ser ${ }^{104}$ by ERK2 [195] promotes the nuclear retention of Snail, which prolongs its half-life. Glycosylation of Snail at Ser ${ }^{112}$ suppresses GSK-3 $\beta$-mediated phosphorylation and thereby stabilizes the protein [196]. SCF FBXL14 also ubiquitylates Snail in the cytosol and triggers its degradation in a manner independent of GSK-3ß-dependent phosphorylation [197].

Snail is also ubiquitylated in the nucleus. Nuclear FBXL5 thus interacts with and mediates the ubiquitylation of Snail, thereby interfering with its binding to DNA [133]. Although this ubiquitylation by $\mathrm{SCF}^{\mathrm{FBXL} 5}$ occurs in the nucleus, Snail is subsequently exported from the nucleus and degraded in the cytosol. FBXW7 is another F-box protein that was shown to mediate the ubiquitylation of Snail in the nucleus $[198,199]$. Snail contains a sequence similar to the CPD (102-PPSPPSPAPS-111), although it has not been demonstrated whether this sequence is essential for the binding of Snail to FBXW7. SCF FBXO11 recognizes Snail via its $\mathrm{NH}_{2}$-terminal SNAG domain $[200,201]$, and FBXO11 deficiency in mice results in neonatal mortality and epidermal thickening in association with the accumulation of Snail family proteins in the epidermis [201]. The atypical F-box protein FBXO45, which does not form an SCF complex but instead associates with the RING finger-type ubiquitin ligase PAM via the COOH-terminal Repeats in splA and ryanodine receptors (SPRY) domain of the latter [202], interacts with Snail via its $\mathrm{NH}_{2}$-terminal F-box domain [203]. $\mathrm{SCF}^{\mathrm{FBXO} 45}, \mathrm{SCF}^{\mathrm{FBXL} 14}$, and $\mathrm{SCF}^{\beta-\operatorname{TrCP}}$ also ubiquitylate the EMT-related transcription factors Slug (SNAI2) and Twist1, suggesting that the corresponding F-box proteins might coordinately regulate EMT [203,204].

Although many F-box proteins contribute to the degradation of Snail, no concentration of mutations in specific regions of the protein is evident in cancer patients (Figure 3C), unlike the situation for c-Myc and cyclin D1. This difference suggests that the impaired degradation of Snail may not be critical for carcinogenesis or cancer progression, and that it may instead contribute to the acquisition of malignant traits characterized by EMT. It is thus possible that specific analysis of advanced cancer cells may reveal the regional concentration of mutations that suppress Snail degradation.

\section{Tumor Suppressors Regulated by F-Box Proteins}

\section{1. $p 53$}

The p53 protein was initially identified in a complex with the large $T$ antigen of simian virus 40 in transformed rodent cells [205,206], and it was first recognized as a tumor suppressor in 1989 [207]. Indeed, the p53 gene is one of the most important tumor suppressor genes, given that it is mutated in $>50 \%$ of all human cancers, a mutation frequency greater than that of any other gene [208]. p53 is a transcription factor that regulates the expression of a wide spectrum of genes that contribute to various cellular functions including apoptosis, cell cycle arrest, senescence, autophagy, DNA repair, angiogenesis, and genome maintenance [209]. In the presence of low-level carcinogenic or genotoxic stimuli, p53 is persistently expressed at a low level. However, in response to cellular stresses including 
DNA damage, hypoxia, oncogene activation, and ribosomal stress, the degradation of p53 is inhibited, resulting in its stabilization and up-regulation of its transcriptional activity [210]. Many E3 ligases have been found to mediate the K48-linked (including Mouse double minute 2 homolog (MDM2) [211,212], PIRH2 [213], TRIM24 [214], CRL4 [215], CRL5 [216], synoviolin [217], constitutively photomorphogenic 1 (COP1) [218], Caspase 8/10-associated RING proteins (CARPs) [219], ARF-BP1 [220,221], WW domain-containing E3 ubiquitin protein ligase 1 (WWP1) [222], and CHIP [223,224]) or K63-linked (such as Tumor necrosis factor receptor-associated factor 6 (TRAF6) [225], TRIM45 [226], Fragile-site associated tumor suppressor (FATS) [227], and CHIP [228]) ubiquitylation of p53.

FBXO22 was first identified as an F-box protein that targets p53 [229] and was later shown to target methylated p53, but not acetylated p53, for degradation in senescent cells [230]. FBXO22 forms a complex with the histone demethylase KDM4 [231], and degradation of p53 dependent on the $\mathrm{SCF}^{\mathrm{FBXO} 22}-\mathrm{KDM} 4 \mathrm{~A}$ complex is essential for induction of the CDK inhibitor p16 and the senescence-associated secretory phenotype [230]. FBXO22 has been implicated as a promoter of tumorigenesis in liver cancer [232], lung cancer [233], and breast cancer [192], suggesting that ubiquitylation of $\mathrm{p} 53$ by $\mathrm{SCF}^{\mathrm{FBXO} 22}$ might underlie such a role.

SCF $^{\text {FBXW7 }}$ was recently shown to contribute to the degradation of p53 [234,235]. Given that $\mathrm{SCF}^{\mathrm{FBXW7}}$-specific targeting of p53 is essential for the recovery of cell proliferation after DNA damage, inhibition of FBXW7 function might sensitize cancer cells to irradiation or chemotherapy by stabilizing p53 and supporting its induction of cell cycle arrest and apoptosis.

\section{2. $p 27^{K I P 1}$}

The CDK inhibitor $\mathrm{p} 27^{\mathrm{KIP} 1}$ was initially identified in cells arrested by exposure to transforming growth factor- $\beta$, contact inhibition, or treatment with lovastatin [236-239]. It negatively regulates the cyclin D-CDK4 complex in $\mathrm{G}_{1}$ phase [240,241]. A low level of p27 ${ }^{\mathrm{KIP} 1}$ expression, together with deregulation of CDK activity, is associated with poor prognosis in a variety of cancers, including those of the colon [242], lung [243], and stomach [244]. Down-regulation of p27 $7^{K I P 1}$ in cancer is attributable to increased turnover mediated by the ubiquitin-proteasome system, rather than to inactivation or point mutation of the $\mathrm{p} 27^{\mathrm{KIP} 1}$ gene [27].

SCF ${ }^{\mathrm{SKP} 2}$ is the best characterized E3 ligase for p2 $7^{\mathrm{KIP} 1}$ degradation. p $27^{\mathrm{KIP} 1}$ is phosphorylated by cyclin E-CDK2 at Thr ${ }^{187}$ and is thereby recruited to the nucleus. SKP2 recognizes the phosphorylated form of $\mathrm{p}^{27^{K I P 1}}$ and binds to its CDK-interacting site in collaboration with CKS1 in order to mediate polyubiquitylation of $\mathrm{p}^{27^{K I P 1}}$ at Lys ${ }^{165}$ in S-G 2 phase $[245,246]$. Overexpression of SKP2 has been found to correlate with reduced levels of $\mathrm{p} 27^{\mathrm{KIP} 1}$ and is a negative prognostic factor in several human cancers including those of the lung [247] and colon [248]. Degradation of p27 ${ }^{K I P 1}$ in $\mathrm{G}_{1}$ phase is mediated by another ubiquitin ligase, Kip1 ubiquitination-promoting complex (KPC), which consists of the RING-finger catalytic subunit KPC1 and the adaptor protein KPC2 [249]. KPC ubiquitylates p27 ${ }^{\text {KIP1 }}$ in the cytoplasm in a manner dependent on Ser ${ }^{10}$ phosphorylation. PIRH2 has also been identified as an E3 ligase for $p 27^{K I P 1}$ [250]. PIRH2 is expressed in late $\mathrm{G}_{1}$ to $\mathrm{S}$ phase, and it targets both nuclear and cytoplasmic $27^{\mathrm{KIP} 1}$ in a phosphorylation-independent manner.

$\mathrm{SCF}^{\mathrm{FBXL12}}$ was recently found to ubiquitylate $\mathrm{p} 27^{\mathrm{KIP1}}$ during $\mathrm{T}$ cell development [251]. FBXL12 is closely related to SKP2 [4], and SCF ${ }^{\mathrm{FBXL12}}$ ubiquitylates $\mathrm{p}^{27^{K I P 1}}$ at Lys ${ }^{165}$, the same site targeted by SCFSKP2 [251]. Notch signaling induced transcription of the SKP2 gene, but not that of the FBXL12 gene, whereas pre-TCR (T cell receptor) signaling-induced expression of the FBXL12 gene but not that of the SKP2 gene. The absence of either SKP2 or FBXL12 in thymocytes similarly attenuated cell proliferation and differentiation in association with the accumulation of $\mathrm{p} 27^{\mathrm{KIP} 1}$, and the absence of both F-box proteins showed an additive effect. These findings suggest that SKP2 and FBXL12 are both required for $\mathrm{T}$ cell development in an identical and additive manner as result of their targeting the same protein. Consideration of the potential of inhibition of the SKP2-p2 $27^{K I P 1}$ pathway for the treatment of T cell leukemia [252] should thus take into account the role of FBXL12. 


\subsection{NRF2}

NF-E2-related factor 2 (NRF2) was first identified as a homolog of the transcription factor NF-E2 and found to interact with the NF-E2 binding site [253]. It was later shown to be a master transcriptional regulator of the cellular antioxidant response. Under normal conditions, NRF2 is constitutively polyubiquitylated by the CRL3 ${ }^{\mathrm{KEAP} 1}$ ubiquitin ligase and thereby targeted for proteasomal degradation. Exposure of cells to oxidative or electrophilic stress, however, results in the direct modification of highly reactive thiols in KEAP1 and consequent inactivation of CRL3 ${ }^{\mathrm{KEAP} 1}$ and stabilization of NRF2 followed by its translocation to the nucleus, where it induces the expression of a battery of cytoprotective genes [254]. Carcinogenesis induced by polycyclic hydrocarbons or nitrosamine was markedly increased in Nrf2-deficient mice [255,256], suggesting that transient NRF2 activation effectively prevents chemical carcinogenesis by increasing antioxidant capabilities. In contrast, however, recent studies also described tumor-promoting roles of NRF2 activation $[257,258]$. Persistent NRF2 activation in cancer cells has been shown to confer therapeutic resistance against cancer agents and aggressive properties.

In addition to CRL3 ${ }^{\text {KEAP1 }}, \mathrm{NRF} 2$ is also ubiquitylated by SCF ${ }^{\beta-\operatorname{TrCP}}[259,260]$. NRF2 harbors a redox-insensitive degron in its Neh6 domain [261] that contains two DSG phosphodegron motifs (343-DpSGIpS-347 and 382-DpSAPGpS-387) targeted by GSK-3 $\beta$. The ubiquitylation of NRF2 by $\mathrm{SCF}^{\beta-\operatorname{TrCP}}$ is independent of CRL3 ${ }^{\mathrm{KEAP} 1}$ activity, with the result that NRF2 can be down-regulated by activation of GSK-3 $\beta$ even in the presence of oxidative stress (when KEAP1 is inactivated), with such down-regulation being a potential approach to prevention of therapeutic resistance due to sustained NRF2 activation.

$\mathrm{SCF}^{\mathrm{FBXO} 22}$ was recently shown to mediate the ubiquitylation and consequent degradation of $\mathrm{BTB}$ domain and $\mathrm{CNC}$ homolog 1 (BACH1), a downstream effector of NRF2 that contributes to control of the transcription of antioxidant genes by NRF2 in a heme-dependent manner [262]. The accumulation of NRF2 in lung cancer promotes the stabilization of BACH1, and the loss of KEAP1 or FBXO22 induces metastasis in a BACH1-dependent manner. Two other E3 ligases, $\mathrm{SCF}^{\mathrm{FBXL} 17}$ and HOIL1, also ubiquitylate BACH1 $[263,264]$ and might therefore act cooperatively with $\mathrm{SCF}^{\mathrm{FBXO} 22}$ to modulate the NRF2 pathway.

\section{Conclusions}

Various F-box proteins have tumor-suppressive or oncogenic functions and have therefore been proposed as potential anticancer targets, with several inhibitors of these proteins having been developed [265]. However, none of these agents have yet entered clinical studies, with the field still being at an early stage. Certain ubiquitin ligases are individually responsible for the integrative degradation of multiple substrates that contribute to a common biological process, with the result that a small number of ubiquitin ligases can degrade a wide variety of substrates. Inhibition of a given F-box protein might therefore have unintended consequences as a result of effects on multiple substrates. In addition, the stability of some individual proteins is regulated by multiple ubiquitin ligases. This situation may reflect fine-grained control of protein function in response to changes in the intracellular environment, with the potential incorporation of multitiered backup mechanisms and operation in a cell- or tissue-dependent manner. Drugs that inhibit one specific F-box protein might therefore be insufficient to halt the development or progression of cancer. It is important, however, to rule out the possibility that experimental findings in this regard are not artifacts due to inadequate analysis. One effective approach to determining which ubiquitin ligase-substrate relations are most relevant to cancer progression is to integrate information on genetic alterations in cancer patients and the results of biochemical analysis, as illustrated by the examples provided in this review. The accumulation of such findings is expected to advance the development of new cancer therapeutics.

Author Contributions: K.Y. and Y.Y. prepared the figures and wrote the first draft of the manuscript. K.I.N. edited the manuscript. All authors have read and agreed to the published version of the manuscript. 
Funding: This work was supported in part by Japan Society for the Promotion of Science KAKENHI grants 17K07171 and 18H05037, Japan Agency for Medical Research and Development (AMED) P-CREATE grant $19 \mathrm{~cm} 0106105 \mathrm{~h} 0004$, and the NAITO foundation.

Acknowledgments: We thank A. Ohta, Y. Okabe, and other laboratory members for help with preparation of the manuscript.

Conflicts of Interest: The authors declare no conflict of interest.

\section{References}

1. Pickart, C.M. Back to the future with ubiquitin. Cell 2004, 116, 181-190. [CrossRef]

2. Senft, D.; Qi, J.; Ronai, Z.A. Ubiquitin ligases in oncogenic transformation and cancer therapy. Nat. Rev. Cancer 2018, 18, 69-88. [CrossRef] [PubMed]

3. Cardozo, T.; Pagano, M. The SCF ubiquitin ligase: Insights into a molecular machine. Nat. Rev. Mol. Cell Biol. 2004, 5, 739-751. [CrossRef] [PubMed]

4. Jin, J.; Cardozo, T.; Lovering, R.C.; Elledge, S.J.; Pagano, M.; Harper, J.W. Systematic analysis and nomenclature of mammalian F-box proteins. Genes Dev. 2004, 18, 2573-2580. [CrossRef]

5. Wang, Z.; Liu, P.; Inuzuka, H.; Wei, W. Roles of F-box proteins in cancer. Nat. Rev. Cancer 2014, 14, $233-247$. [CrossRef] [PubMed]

6. Meszaros, B.; Kumar, M.; Gibson, T.J.; Uyar, B.; Dosztanyi, Z. Degrons in cancer. Sci. Signal. $2017,10$. [CrossRef]

7. Bai, C.; Richman, R.; Elledge, S.J. Human cyclin F. EMBO J. 1994, 13, 6087-6098. [CrossRef]

8. D'Angiolella, V.; Donato, V.; Vijayakumar, S.; Saraf, A.; Florens, L.; Washburn, M.P.; Dynlacht, B.; Pagano, M. $\mathrm{SCF}$ Cyclin $\mathrm{F}$ controls centrosome homeostasis and mitotic fidelity through CP110 degradation. Nature 2010, 466, 138-142. [CrossRef]

9. Walter, D.; Hoffmann, S.; Komseli, E.S.; Rappsilber, J.; Gorgoulis, V.; Sorensen, C.S. SCFCyclin F-dependent degradation of CDC6 suppresses DNA re-replication. Nat. Commun. 2016, 7, 10530. [CrossRef]

10. D'Angiolella, V.; Donato, V.; Forrester, F.M.; Jeong, Y.T.; Pellacani, C.; Kudo, Y.; Saraf, A.; Florens, L.; Washburn, M.P.; Pagano, M. Cyclin F-mediated degradation of ribonucleotide reductase M2 controls genome integrity and DNA repair. Cell 2012, 149, 1023-1034. [CrossRef]

11. Klein, D.K.; Hoffmann, S.; Ahlskog, J.K.; O'Hanlon, K.; Quaas, M.; Larsen, B.D.; Rolland, B.; Rosner, H.I.; Walter, D.; Kousholt, A.N.; et al. Cyclin F suppresses B-Myb activity to promote cell cycle checkpoint control. Nat. Commun. 2015, 6, 5800. [CrossRef] [PubMed]

12. Dankert, J.F.; Rona, G.; Clijsters, L.; Geter, P.; Skaar, J.R.; Bermudez-Hernandez, K.; Sassani, E.; Fenyo, D.; Ueberheide, B.; Schneider, R.; et al. Cyclin F-mediated degradation of SLBP limits H2A.X accumulation and apoptosis upon genotoxic stress in G2. Mol. Cell 2016, 64, 507-519. [CrossRef] [PubMed]

13. Clijsters, L.; Hoencamp, C.; Calis, J.J.A.; Marzio, A.; Handgraaf, S.M.; Cuitino, M.C.; Rosenberg, B.R.; Leone, G.; Pagano, M. Cyclin F controls cell-cycle transcriptional outputs by directing the degradation of the three activator E2Fs. Mol. Cell 2019, 74, 1264-1277.e7. [CrossRef]

14. Burdova, K.; Yang, H.; Faedda, R.; Hume, S.; Chauhan, J.; Ebner, D.; Kessler, B.M.; Vendrell, I.; Drewry, D.H.; Wells, C.I.; et al. E2F1 proteolysis via SCF-cyclin F underlies synthetic lethality between cyclin F loss and Chk1 inhibition. EMBO J. 2019, 38, e101443. [CrossRef] [PubMed]

15. Elia, A.E.; Boardman, A.P.; Wang, D.C.; Huttlin, E.L.; Everley, R.A.; Dephoure, N.; Zhou, C.; Koren, I.; Gygi, S.P.; Elledge, S.J. Quantitative proteomic atlas of ubiquitination and acetylation in the DNA damage response. Mol. Cell 2015, 59, 867-881. [CrossRef] [PubMed]

16. Deshmukh, R.S.; Sharma, S.; Das, S. Cyclin F-dependent degradation of RBPJ inhibits IDH1(R132H)-mediated tumorigenesis. Cancer Res. 2018, 78, 6386-6398.

17. Fu, J.; Qiu, H.; Cai, M.; Pan, Y.; Cao, Y.; Liu, L.; Yun, J.; Zhang, C.Z. Low cyclin F expression in hepatocellular carcinoma associates with poor differentiation and unfavorable prognosis. Cancer Sci. 2013, 104, 508-515. [CrossRef]

18. Zhang, H.; Kobayashi, R.; Galaktionov, K.; Beach, D. p19 $9^{\text {Skp1 }}$ and p45 $5^{\text {Skp2 }}$ are essential elements of the cyclin A-CDK2 S phase kinase. Cell 1995, 82, 915-925. [CrossRef]

19. Tsvetkov, L.M.; Yeh, K.H.; Lee, S.J.; Sun, H.; Zhang, H. p2 $7^{\text {Kip} 1 ~ u b i q u i t i n a t i o n ~ a n d ~ d e g r a d a t i o n ~ i s ~ r e g u l a t e d ~}$ by the SCF ${ }^{\text {Skp2 }}$ complex through phosphorylated Thr187 in p27. Curr. Biol. 1999, 9, 661-664. [CrossRef] 
20. Carrano, A.C.; Eytan, E.; Hershko, A.; Pagano, M. SKP2 is required for ubiquitin-mediated degradation of the CDK inhibitor p27. Nat. Cell Biol. 1999, 1, 193-199. [CrossRef]

21. Nakayama, K.; Nagahama, H.; Minamishima, Y.A.; Matsumoto, M.; Nakamichi, I.; Kitagawa, K.; Shirane, M.; Tsunematsu, R.; Tsukiyama, T.; Ishida, N.; et al. Targeted disruption of Skp2 results in accumulation of cyclin E and p27 Kip1, polyploidy and centrosome overduplication. EMBO J. 2000, 19, 2069-2081. [CrossRef]

22. Nakayama, K.; Nagahama, H.; Minamishima, Y.A.; Miyake, S.; Ishida, N.; Hatakeyama, S.; Kitagawa, M.; Iemura, S.; Natsume, T.; Nakayama, K.I. Skp2-mediated degradation of p27 regulates progression into mitosis. Dev. Cell 2004, 6, 661-672. [CrossRef]

23. Kossatz, U.; Dietrich, N.; Zender, L.; Buer, J.; Manns, M.P.; Malek, N.P. Skp2-dependent degradation of p27kip1 is essential for cell cycle progression. Genes Dev. 2004, 18, 2602-2607. [CrossRef]

24. Kamura, T.; Hara, T.; Kotoshiba, S.; Yada, M.; Ishida, N.; Imaki, H.; Hatakeyama, S.; Nakayama, K.; Nakayama, K.I. Degradation of p57Kip2 mediated by SCF ${ }^{\text {Skp2 }}$-dependent ubiquitylation. Proc. Natl. Acad. Sci. USA 2003, 100, 10231-10236. [CrossRef]

25. Yu, Z.K.; Gervais, J.L.; Zhang, H. Human CUL-1 associates with the SKP1/SKP2 complex and regulates p21 ${ }^{\mathrm{CIP} 1 / \mathrm{WAF} 1}$ and cyclin D proteins. Proc. Natl. Acad. Sci. USA 1998, 95, 11324-11329. [CrossRef]

26. Bornstein, G.; Bloom, J.; Sitry-Shevah, D.; Nakayama, K.; Pagano, M.; Hershko, A. Role of the SCF ${ }^{\text {Skp2 }}$ ubiquitin ligase in the degradation of $\mathrm{p}^{2} 1^{\mathrm{Cip} 1}$ in S phase. J. Biol. Chem. 2003, 278, 25752-25757. [CrossRef]

27. Nakayama, K.I.; Nakayama, K. Ubiquitin ligases: Cell-cycle control and cancer. Nat. Rev. Cancer 2006, 6, 369-381. [CrossRef]

28. Mansour, M.A. Ubiquitination: Friend and foe in cancer. Int. J. Biochem. Cell Biol. 2018, 101, 80-93. [CrossRef]

29. Yang, G.; Ayala, G.; De Marzo, A.; Tian, W.; Frolov, A.; Wheeler, T.M.; Thompson, T.C.; Harper, J.W. Elevated Skp2 protein expression in human prostate cancer: Association with loss of the cyclin-dependent kinase inhibitor p27 and PTEN and with reduced recurrence-free survival. Clin. Cancer. Res. 2002, 8, 3419-3426.

30. Signoretti, S.; Di Marcotullio, L.; Richardson, A.; Ramaswamy, S.; Isaac, B.; Rue, M.; Monti, F.; Loda, M.; Pagano, M. Oncogenic role of the ubiquitin ligase subunit Skp2 in human breast cancer. J. Clin. Invest. 2016, 126, 4387. [CrossRef]

31. Foster, J.S.; Fernando, R.I.; Ishida, N.; Nakayama, K.I.; Wimalasena, J. Estrogens down-regulate p27Kip1 in breast cancer cells through Skp2 and through nuclear export mediated by the ERK pathway. J. Biol. Chem. 2003, 278, 41355-41366. [CrossRef]

32. Zhu, C.Q.; Blackhall, F.H.; Pintilie, M.; Iyengar, P.; Liu, N.; Ho, J.; Chomiak, T.; Lau, D.; Winton, T.; Shepherd, F.A.; et al. Skp2 gene copy number aberrations are common in non-small cell lung carcinoma, and its overexpression in tumors with ras mutation is a poor prognostic marker. Clin. Cancer. Res. 2004, 10, 1984-1991. [CrossRef]

33. Shim, E.H.; Johnson, L.; Noh, H.L.; Kim, Y.J.; Sun, H.; Zeiss, C.; Zhang, H. Expression of the F-box protein SKP2 induces hyperplasia, dysplasia, and low-grade carcinoma in the mouse prostate. Cancer Res. 2003, 63, 1583-1588.

34. Latres, E.; Chiarle, R.; Schulman, B.A.; Pavletich, N.P.; Pellicer, A.; Inghirami, G.; Pagano, M. Role of the F-box protein Skp2 in lymphomagenesis. Proc. Natl. Acad. Sci. USA 2001, 98, 2515-2520. [CrossRef]

35. Agarwal, A.; Bumm, T.G.; Corbin, A.S.; O’Hare, T.; Loriaux, M.; VanDyke, J.; Willis, S.G.; Deininger, J.; Nakayama, K.I.; Druker, B.J.; et al. Absence of SKP2 expression attenuates BCR-ABL-induced myeloproliferative disease. Blood 2008, 112, 1960-1970. [CrossRef]

36. Lin, H.K.; Chen, Z.; Wang, G.; Nardella, C.; Lee, S.W.; Chan, C.H.; Yang, W.L.; Wang, J.; Egia, A.; Nakayama, K.I.; et al. Skp2 targeting suppresses tumorigenesis by Arf-p53-independent cellular senescence. Nature 2010, 464, 374-379. [CrossRef]

37. Tedesco, D.; Lukas, J.; Reed, S.I. The pRb-related protein p130 is regulated by phosphorylation-dependent proteolysis via the protein-ubiquitin ligase $\mathrm{SCF}^{\mathrm{Skp} 2}$. Genes Dev. 2002, 16, 2946-2957. [CrossRef]

38. Huang, H.; Regan, K.M.; Wang, F.; Wang, D.; Smith, D.I.; van Deursen, J.M.; Tindall, D.J. Skp2 inhibits FOXO1 in tumor suppression through ubiquitin-mediated degradation. Proc. Natl. Acad. Sci. USA 2005, 102, 1649-1654. [CrossRef]

39. Kiernan, R.E.; Emiliani, S.; Nakayama, K.; Castro, A.; Labbe, J.C.; Lorca, T.; Nakayama Ki, K.; Benkirane, M. Interaction between cyclin $\mathrm{T} 1$ and $\mathrm{SCF}^{\mathrm{SKP} 2}$ targets $\mathrm{CDK} 9$ for ubiquitination and degradation by the proteasome. Mol. Cell. Biol. 2001, 21, 7956-7970. [CrossRef] 
40. Jiang, H.; Chang, F.C.; Ross, A.E.; Lee, J.; Nakayama, K.; Nakayama, K.; Desiderio, S. Ubiquitylation of RAG-2 by Skp2-SCF links destruction of the V(D)J recombinase to the cell cycle. Mol. Cell 2005, 18, 699-709. [CrossRef]

41. Charrasse, S.; Carena, I.; Brondani, V.; Klempnauer, K.H.; Ferrari, S. Degradation of B-Myb by ubiquitin-mediated proteolysis: Involvement of the Cdc34-SCF ${ }^{45 S k p 2}$ pathway. Oncogene 2000, 19, 2986-2995. [CrossRef]

42. Chan, C.H.; Li, C.F.; Yang, W.L.; Gao, Y.; Lee, S.W.; Feng, Z.; Huang, H.Y.; Tsai, K.K.; Flores, L.G.; Shao, Y.; et al. The Skp2-SCF E3 ligase regulates Akt ubiquitination, glycolysis, herceptin sensitivity, and tumorigenesis. Cell 2012, 149, 1098-1111. [CrossRef]

43. Yao, F.; Zhou, Z.; Kim, J.; Hang, Q.; Xiao, Z.; Ton, B.N.; Chang, L.; Liu, N.; Zeng, L.; Wang, W.; et al. SKP2and OTUD1-regulated non-proteolytic ubiquitination of YAP promotes YAP nuclear localization and activity. Nat. Commun. 2018, 9, 2269. [CrossRef]

44. Ruan, D.; He, J.; Li, C.F.; Lee, H.J.; Liu, J.; Lin, H.K.; Chan, C.H. Skp2 deficiency restricts the progression and stem cell features of castration-resistant prostate cancer by destabilizing Twist. Oncogene 2017, 36, 4299-4310. [CrossRef]

45. Wu, J.; Zhang, X.; Zhang, L.; Wu, C.Y.; Rezaeian, A.H.; Chan, C.H.; Li, J.M.; Wang, J.; Gao, Y.; Han, F.; et al. Skp2 E3 ligase integrates ATM activation and homologous recombination repair by ubiquitinating NBS1. Mol. Cell 2012, 46, 351-361. [CrossRef]

46. Jin, G.; Lee, S.W.; Zhang, X.; Cai, Z.; Gao, Y.; Chou, P.C.; Rezaeian, A.H.; Han, F.; Wang, C.Y.; Yao, J.C.; et al. Skp2-mediated RagA ubiquitination elicits a negative feedback to prevent amino-acid-dependent mTORC1 hyperactivation by recruiting GATOR1. Mol. Cell 2015, 58, 989-1000. [CrossRef]

47. Liao, Y.; Liu, N.; Xia, X.; Guo, Z.; Li, Y.; Jiang, L.; Zhou, R.; Tang, D.; Huang, H.; Liu, J. USP10 modulates the SKP2/Bcr-Abl axis via stabilizing SKP2 in chronic myeloid leukemia. Cell Discov. 2019, 5, 24. [CrossRef]

48. Wang, J.Y.; Liu, G.Z.; Wilmott, J.S.; La, T.; Feng, Y.C.; Yari, H.; Yan, X.G.; Thorne, R.F.; Scolyer, R.A.; Zhang, X.D.; et al. Skp2-mediated stabilization of MTH1 promotes survival of melanoma cells upon oxidative stress. Cancer Res. 2017, 77, 6226-6239. [CrossRef]

49. Wu, J.; Huang, Y.F.; Zhou, X.K.; Zhang, W.; Lian, Y.F.; Lv, X.B.; Gao, X.R.; Lin, H.K.; Zeng, Y.X.; Huang, J.Q. Skp2 is required for Aurora B activation in cell mitosis and spindle checkpoint. Cell Cycle 2015, 14, 3877-3884. [CrossRef]

50. Yu, X.; Wang, R.; Zhang, Y.; Zhou, L.; Wang, W.; Liu, H.; Li, W. Skp2-mediated ubiquitination and mitochondrial localization of Akt drive tumor growth and chemoresistance to cisplatin. Oncogene 2019, 38, 7457-7472. [CrossRef]

51. Clement, E.; Inuzuka, H.; Nihira, N.T.; Wei, W.; Toker, A. Skp2-dependent reactivation of AKT drives resistance to PI3K inhibitors. Sci. Signal. 2018, 11. [CrossRef]

52. Zhang, S.; Chen, Q.; Liu, Q.; Li, Y.; Sun, X.; Hong, L.; Ji, S.; Liu, C.; Geng, J.; Zhang, W.; et al. Hippo signaling suppresses cell ploidy and tumorigenesis through Skp2. Cancer Cell 2017, 31, 669-684.e7. [CrossRef]

53. Cai, Z.; Moten, A.; Peng, D.; Hsu, C.C.; Pan, B.S.; Manne, R.; Li, H.Y.; Lin, H.K. The Skp2 pathway: A critical target for cancer therapy. Semin. Cancer Biol. 2020. [CrossRef]

54. Chan, C.H.; Morrow, J.K.; Li, C.F.; Gao, Y.; Jin, G.; Moten, A.; Stagg, L.J.; Ladbury, J.E.; Cai, Z.; Xu, D.; et al. Pharmacological inactivation of Skp2 SCF ubiquitin ligase restricts cancer stem cell traits and cancer progression. Cell 2013, 154, 556-568. [CrossRef]

55. Chen, Q.; Xie, W.; Kuhn, D.J.; Voorhees, P.M.; Lopez-Girona, A.; Mendy, D.; Corral, L.G.; Krenitsky, V.P.; $\mathrm{Xu}, \mathrm{W}$.; Moutouh-de Parseval, L.; et al. Targeting the p27 E3 ligase SCF ${ }^{\text {Skp2 }}$ results in p27- and Skp2-mediated cell-cycle arrest and activation of autophagy. Blood 2008, 111, 4690-4699. [CrossRef]

56. Ungermannova, D.; Lee, J.; Zhang, G.; Dallmann, H.G.; McHenry, C.S.; Liu, X. High-throughput screening AlphaScreen assay for identification of small-molecule inhibitors of ubiquitin E3 ligase SCF ${ }^{\text {Skp2-Cks1. }}$. J. Biomol. Screen. 2013, 18, 910-920. [CrossRef]

57. Ooi, L.C.; Watanabe, N.; Futamura, Y.; Sulaiman, S.F.; Darah, I.; Osada, H. Identification of small molecule inhibitors of p27Kip1 ubiquitination by high-throughput screening. Cancer Sci. 2013, 104, 1461-1467. [CrossRef]

58. Singh, R.; Sran, A.; Carroll, D.C.; Huang, J.; Tsvetkov, L.; Zhou, X.; Sheung, J.; McLaughlin, J.; Issakani, S.D.; Payan, D.G.; et al. Developing structure-activity relationships from an HTS hit for inhibition of the Cks1-Skp2 protein-protein interaction. Bioorg. Med. Chem. Lett. 2015, 25, 5199-5202. [CrossRef] 
59. Jiang, W.; Lin, M.; Wang, Z. Dioscin: A new potential inhibitor of Skp2 for cancer therapy. EBioMedicine 2020, 51, 102593. [CrossRef]

60. Wei, W.; Ayad, N.G.; Wan, Y.; Zhang, G.J.; Kirschner, M.W.; Kaelin, W.G., Jr. Degradation of the SCF component Skp2 in cell-cycle phase G1 by the anaphase-promoting complex. Nature 2004, 428, 194-198. [CrossRef]

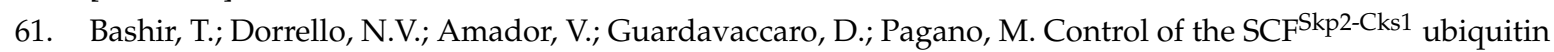
ligase by the APC/C ${ }^{C d h 1}$ ubiquitin ligase. Nature 2004, 428, 190-193. [CrossRef] [PubMed]

62. Hubbard, E.J.; Wu, G.; Kitajewski, J.; Greenwald, I. sel-10, a negative regulator of lin-12 activity in Caenorhabditis elegans, encodes a member of the CDC4 family of proteins. Genes Dev. 1997, 11, 3182-3193. [CrossRef]

63. Welcker, M.; Clurman, B.E. FBW7 ubiquitin ligase: A tumour suppressor at the crossroads of cell division, growth and differentiation. Nat. Rev. Cancer 2008, 8, 83-93. [CrossRef]

64. Takeishi, S.; Nakayama, K.I. Role of Fbxw7 in the maintenance of normal stem cells and cancer-initiating cells. Br. J. Cancer 2014, 111, 1054-1059. [CrossRef]

65. Yumimoto, K.; Matsumoto, M.; Onoyama, I.; Imaizumi, K.; Nakayama, K.I. F-box and WD repeat domain-containing-7 (Fbxw7) protein targets endoplasmic reticulum-anchored osteogenic and chondrogenic transcriptional factors for degradation. J. Biol. Chem. 2013, 288, 28488-28502. [CrossRef]

66. Hao, B.; Oehlmann, S.; Sowa, M.E.; Harper, J.W.; Pavletich, N.P. Structure of a Fbw7-Skp1-cyclin E complex: Multisite-phosphorylated substrate recognition by SCF ubiquitin ligases. Mol. Cell 2007, 26, 131-143. [CrossRef]

67. Yumimoto, K.; Nakayama, K.I. Recent insight into the role of FBXW7 as a tumor suppressor. Semin. Cancer Biol. 2020. [CrossRef]

68. Yada, M.; Hatakeyama, S.; Kamura, T.; Nishiyama, M.; Tsunematsu, R.; Imaki, H.; Ishida, N.; Okumura, F.; Nakayama, K.; Nakayama, K.I. Phosphorylation-dependent degradation of c-Myc is mediated by the F-box protein Fbw7. EMBO J. 2004, 23, 2116-2125. [CrossRef]

69. Welcker, M.; Orian, A.; Jin, J.; Grim, J.E.; Harper, J.W.; Eisenman, R.N.; Clurman, B.E. The Fbw7 tumor suppressor regulates glycogen synthase kinase 3 phosphorylation-dependent c-Myc protein degradation. Proc. Natl. Acad. Sci. USA 2004, 101, 9085-9090. [CrossRef]

70. Gupta-Rossi, N.; Bail, O.L.; Gonen, H.; Brou, C.; Logeat, F.; Six, E.; Ciechanover, A.; Israel, A. Functional interaction between SEL-10, an F-box protein, and the nuclear form of activated Notch1 receptor. J. Biol. Chem. 2001, 276, 34371-34378. [CrossRef]

71. Oberg, C.; Li, J.; Pauley, A.; Wolf, E.; Gurney, M.; Lendahl, U. The Notch intracellular domain is ubiquitinated and negatively regulated by the mammalian Sel-10 homolog. J. Biol. Chem. 2001, 276, 35847-35853. [CrossRef]

72. Wei, W.; Jin, J.; Schlisio, S.; Harper, J.W.; Kaelin, W.G., Jr. The v-Jun point mutation allows c-Jun to escape GSK3-dependent recognition and destruction by the Fbw7 ubiquitin ligase. Cancer Cell 2005, 8, 25-33. [CrossRef]

73. Nateri, A.S.; Riera-Sans, L.; Da Costa, C.; Behrens, A. The ubiquitin ligase $\mathrm{SCF}^{\mathrm{Fbw}}$ antagonizes apoptotic JNK signaling. Science 2004, 303, 1374-1378. [CrossRef]

74. Koepp, D.M.; Schaefer, L.K.; Ye, X.; Keyomarsi, K.; Chu, C.; Harper, J.W.; Elledge, S.J. Phosphorylation-dependent ubiquitination of cyclin $\mathrm{E}$ by the $\mathrm{SCF}^{\mathrm{Fbw}}$ ubiquitin ligase. Science 2001, 294, 173-177. [CrossRef] [PubMed]

75. Moberg, K.H.; Bell, D.W.; Wahrer, D.C.; Haber, D.A.; Hariharan, I.K. Archipelago regulates Cyclin E levels in Drosophila and is mutated in human cancer cell lines. Nature 2001, 413, 311-316. [CrossRef]

76. Strohmaier, H.; Spruck, C.H.; Kaiser, P.; Won, K.A.; Sangfelt, O.; Reed, S.I. Human F-box protein hCdc4 targets cyclin $\mathrm{E}$ for proteolysis and is mutated in a breast cancer cell line. Nature 2001, 413, 316-322. [CrossRef]

77. Liu, N.; Li, H.; Li, S.; Shen, M.; Xiao, N.; Chen, Y.; Wang, Y.; Wang, W.; Wang, R.; Wang, Q.; et al. The Fbw7/human CDC4 tumor suppressor targets proproliferative factor KLF5 for ubiquitination and degradation through multiple phosphodegron motifs. J. Biol. Chem. 2010, 285, 18858-18867. [CrossRef]

78. Zhao, D.; Zheng, H.Q.; Zhou, Z.; Chen, C. The Fbw7 tumor suppressor targets KLF5 for ubiquitin-mediated degradation and suppresses breast cell proliferation. Cancer Res. 2010, 70, 4728-4738. [CrossRef]

79. Inuzuka, H.; Shaik, S.; Onoyama, I.; Gao, D.; Tseng, A.; Maser, R.S.; Zhai, B.; Wan, L.; Gutierrez, A.; Lau, A.W.; et al. $\mathrm{SCF}^{\mathrm{FBW7}}$ regulates cellular apoptosis by targeting MCL1 for ubiquitylation and destruction. Nature 2011, 471, 104-109. [CrossRef] 
80. Wertz, I.E.; Kusam, S.; Lam, C.; Okamoto, T.; Sandoval, W.; Anderson, D.J.; Helgason, E.; Ernst, J.A.; Eby, M.; Liu, J.; et al. Sensitivity to antitubulin chemotherapeutics is regulated by MCL1 and FBW7. Nature 2011, 471, 110-114. [CrossRef]

81. Yalla, K.; Elliott, C.; Day, J.P.; Findlay, J.; Barratt, S.; Hughes, Z.A.; Wilson, L.; Whiteley, E.; Popiolek, M.; Li, Y.; et al. FBXW7 regulates DISC1 stability via the ubiquitin-proteosome system. Mol. Psychiatry 2018, 23, 1278-1286. [CrossRef] [PubMed]

82. Weng, A.P.; Ferrando, A.A.; Lee, W.; Morris, J.P., 4th; Silverman, L.B.; Sanchez-Irizarry, C.; Blacklow, S.C.; Look, A.T.; Aster, J.C. Activating mutations of NOTCH1 in human T cell acute lymphoblastic leukemia. Science 2004, 306, 269-271. [CrossRef] [PubMed]

83. Callens, C.; Baleydier, F.; Lengline, E.; Abdelali, R.B.; Petit, A.; Villarese, P.; Cieslak, A.; Minard-Colin, V.; Rullier, A.; Moreau, A.; et al. Clinical impact of NOTCH1 and/or FBXW7 mutations, FLASH deletion, and TCR status in pediatric T-cell lymphoblastic lymphoma. J. Clin. Oncol. 2012, 30, 1966-1973. [CrossRef] [PubMed]

84. Bonn, B.R.; Rohde, M.; Zimmermann, M.; Krieger, D.; Oschlies, I.; Niggli, F.; Wrobel, G.; Attarbaschi, A.; Escherich, G.; Klapper, W.; et al. Incidence and prognostic relevance of genetic variations in T-cell lymphoblastic lymphoma in childhood and adolescence. Blood 2013, 121, 3153-3160. [CrossRef] [PubMed]

85. McConnell, B.B.; Bialkowska, A.B.; Nandan, M.O.; Ghaleb, A.M.; Gordon, F.J.; Yang, V.W. Haploinsufficiency of Kruppel-like factor 5 rescues the tumor-initiating effect of the $A p c^{M i n}$ mutation in the intestine. Cancer Res. 2009, 69, 4125-4133. [CrossRef] [PubMed]

86. Nandan, M.O.; Ghaleb, A.M.; McConnell, B.B.; Patel, N.V.; Robine, S.; Yang, V.W. Kruppel-like factor 5 is a crucial mediator of intestinal tumorigenesis in mice harboring combined $A p c^{M i n}$ and KRAS V12 mutations. Mol. Cancer 2010, 9, 63. [CrossRef] [PubMed]

87. Huang, H.L.; Weng, H.Y.; Wang, L.Q.; Yu, C.H.; Huang, Q.J.; Zhao, P.P.; Wen, J.Z.; Zhou, H.; Qu, L.H. Triggering Fbw7-mediated proteasomal degradation of c-Myc by oridonin induces cell growth inhibition and apoptosis. Mol. Cancer Ther. 2012, 11, 1155-1165. [CrossRef]

88. Gao, J.; Azmi, A.S.; Aboukameel, A.; Kauffman, M.; Shacham, S.; Abou-Samra, A.B.; Mohammad, R.M. Nuclear retention of Fbw7 by specific inhibitors of nuclear export leads to Notch1 degradation in pancreatic cancer. Oncotarget 2014, 5, 3444-3454. [CrossRef]

89. Ma, J.; Cheng, L.; Liu, H.; Zhang, J.; Shi, Y.; Zeng, F.; Miele, L.; Sarkar, F.H.; Xia, J.; Wang, Z. Genistein down-regulates miR-223 expression in pancreatic cancer cells. Curr. Drug Targets 2013, 14, 1150-1156. [CrossRef]

90. Yumimoto, K.; Akiyoshi, S.; Ueo, H.; Sagara, Y.; Onoyama, I.; Ueo, H.; Ohno, S.; Mori, M.; Mimori, K.; Nakayama, K.I. F-box protein FBXW7 inhibits cancer metastasis in a non-cell-autonomous manner. J. Clin. Invest. 2015, 125, 621-635. [CrossRef]

91. Margottin, F.; Bour, S.P.; Durand, H.; Selig, L.; Benichou, S.; Richard, V.; Thomas, D.; Strebel, K.; Benarous, R. A novel human WD protein, h- $\beta \operatorname{TrCP}$, that interacts with HIV-1 Vpu connects CD4 to the ER degradation pathway through an F-box motif. Mol. Cell 1998, 1, 565-574. [CrossRef]

92. Winston, J.T.; Strack, P.; Beer-Romero, P.; Chu, C.Y.; Elledge, S.J.; Harper, J.W. The SCF ${ }^{\beta-T R C P}$-ubiquitin ligase complex associates specifically with phosphorylated destruction motifs in $\mathrm{I} \kappa \mathrm{B} \alpha$ and $\beta$-catenin and stimulates IkappaBalpha ubiquitination in vitro. Genes Dev. 1999, 13, 270-283. [CrossRef]

93. Hart, M.; Concordet, J.P.; Lassot, I.; Albert, I.; del los Santos, R.; Durand, H.; Perret, C.; Rubinfeld, B.; Margottin, F.; Benarous, R.; et al. The F-box protein $\beta$-TrCP associates with phosphorylated beta-catenin and regulates its activity in the cell. Curr. Biol. 1999, 9, 207-210. [CrossRef]

94. Kitagawa, M.; Hatakeyama, S.; Shirane, M.; Matsumoto, M.; Ishida, N.; Hattori, K.; Nakamichi, I.; Kikuchi, A.; Nakayama, K.; Nakayama, K. An F-box protein, FWD1, mediates ubiquitin-dependent proteolysis of $\beta$-catenin. EMBO J. 1999, 18, 2401-2410. [CrossRef]

95. Nakayama, K.; Hatakeyama, S.; Maruyama, S.; Kikuchi, A.; Onoe, K.; Good, R.A.; Nakayama, K.I. Impaired degradation of inhibitory subunit of NF-KB (IKB) and $\beta$-catenin as a result of targeted disruption of the $\beta$-TrCP1 gene. Proc. Natl. Acad. Sci. USA 2003, 100, 8752-8757. [CrossRef] [PubMed]

96. Yaron, A.; Hatzubai, A.; Davis, M.; Lavon, I.; Amit, S.; Manning, A.M.; Andersen, J.S.; Mann, M.; Mercurio, F.; Ben-Neriah, Y. Identification of the receptor component of the IkB $\alpha$-ubiquitin ligase. Nature 1998, 396, 590-594. [CrossRef] [PubMed] 
97. Tan, P.; Fuchs, S.Y.; Chen, A.; Wu, K.; Gomez, C.; Ronai, Z.; Pan, Z.Q. Recruitment of a ROC1-CUL1 ubiquitin ligase by Skp1 and HOS to catalyze the ubiquitination of IKB $\alpha$. Mol. Cell 1999, 3, 527-533. [CrossRef]

98. Shirane, M.; Hatakeyama, S.; Hattori, K.; Nakayama, K.; Nakayama, K. Common pathway for the ubiquitination of $\mathrm{I} \kappa \mathrm{B} \alpha, \mathrm{I} \kappa \mathrm{B} \beta$, and $\mathrm{I} \kappa \mathrm{B} \varepsilon$ mediated by the F-box protein FWD1. J. Biol. Chem. 1999, 274, 28169-28174. [CrossRef] [PubMed]

99. Wu, C.; Ghosh, S. $\beta$-TrCP mediates the signal-induced ubiquitination of IкB $\beta$. J. Biol. Chem. 1999, 274, 29591-29594. [CrossRef] [PubMed]

100. Hattori, K.; Hatakeyama, S.; Shirane, M.; Matsumoto, M.; Nakayama, K.I. Molecular dissection of the interactions among $\mathrm{I} \kappa \mathrm{B} \alpha, \mathrm{FWD} 1$, and Skp1 required for ubiquitin-mediated proteolysis of IkB $\alpha$. J. Biol. Chem. 1999, 274, 29641-29647. [CrossRef]

101. Busino, L.; Donzelli, M.; Chiesa, M.; Guardavaccaro, D.; Ganoth, D.; Dorrello, N.V.; Hershko, A.; Pagano, M.; Draetta, G.F. Degradation of Cdc25A by $\beta$-TrCP during $S$ phase and in response to DNA damage. Nature 2003, 426, 87-91. [CrossRef] [PubMed]

102. Jin, J.; Shirogane, T.; Xu, L.; Nalepa, G.; Qin, J.; Elledge, S.J.; Harper, J.W. SCF ${ }^{\beta-T R C P}$ links Chk1 signaling to degradation of the Cdc25A protein phosphatase. Genes Dev. 2003, 17, 3062-3074. [CrossRef] [PubMed]

103. Kanemori, Y.; Uto, K.; Sagata, N. $\beta$-TrCP recognizes a previously undescribed nonphosphorylated destruction motif in Cdc25A and Cdc25B phosphatases. Proc. Natl. Acad. Sci. USA 2005, 102, 6279-6284. [CrossRef] [PubMed]

104. Uchida, S.; Watanabe, N.; Kudo, Y.; Yoshioka, K.; Matsunaga, T.; Ishizaka, Y.; Nakagama, H.; Poon, R.Y.; Yamashita, K. SCF ${ }^{\beta \operatorname{TrCP}}$ mediates stress-activated MAPK-induced Cdc25B degradation. J. Cell Sci. 2011, 124, 2816-2825. [CrossRef]

105. Watanabe, N.; Arai, H.; Nishihara, Y.; Taniguchi, M.; Watanabe, N.; Hunter, T.; Osada, H. M-phase kinases induce phospho-dependent ubiquitination of somatic Wee1 by $\mathrm{SCF}^{\beta-T r C P}$. Proc. Natl. Acad. Sci. USA 2004, 101, 4419-4424. [CrossRef]

106. Zhou, B.P.; Deng, J.; Xia, W.; Xu, J.; Li, Y.M.; Gunduz, M.; Hung, M.C. Dual regulation of Snail by GSK-3 $\beta$-mediated phosphorylation in control of epithelial-mesenchymal transition. Nat. Cell Biol. 2004, 6, 931-940. [CrossRef]

107. Yook, J.I.; Li, X.Y.; Ota, I.; Fearon, E.R.; Weiss, S.J. Wnt-dependent regulation of the E-cadherin repressor snail. J. Biol. Chem. 2005, 280, 11740-11748. [CrossRef]

108. Tsai, W.B.; Chung, Y.M.; Zou, Y.; Park, S.H.; Xu, Z.; Nakayama, K.; Lin, S.H.; Hu, M.C. Inhibition of FOXO3 tumor suppressor function by $\beta \operatorname{TrCP} 1$ through ubiquitin-mediated degradation in a tumor mouse model. PLoS ONE 2010, 5, e11171. [CrossRef]

109. Westbrook, T.F.; Hu, G.; Ang, X.L.; Mulligan, P.; Pavlova, N.N.; Liang, A.; Leng, Y.; Maehr, R.; Shi, Y.; Harper, J.W.; et al. SCF ${ }^{\beta-T R C P}$ controls oncogenic transformation and neural differentiation through REST degradation. Nature 2008, 452, 370-374. [CrossRef]

110. Dorrello, N.V.; Peschiaroli, A.; Guardavaccaro, D.; Colburn, N.H.; Sherman, N.E.; Pagano, M. S6K1- and $\beta$ TRCP-mediated degradation of PDCD4 promotes protein translation and cell growth. Science 2006, 314, 467-471. [CrossRef]

111. Ougolkov, A.; Zhang, B.; Yamashita, K.; Bilim, V.; Mai, M.; Fuchs, S.Y.; Minamoto, T. Associations among $\beta$-TrCP, an E3 ubiquitin ligase receptor, $\beta$-catenin, and NF- $\mathrm{KB}$ in colorectal cancer. J. Natl. Cancer Inst. 2004, 96, 1161-1170. [CrossRef] [PubMed]

112. Muerkoster, S.; Arlt, A.; Sipos, B.; Witt, M.; Grossmann, M.; Kloppel, G.; Kalthoff, H.; Folsch, U.R.; Schafer, H. Increased expression of the E3-ubiquitin ligase receptor subunit $\beta$ TRCP1 relates to constitutive nuclear factor- $\mathrm{kB}$ activation and chemoresistance in pancreatic carcinoma cells. Cancer Res. 2005, 65, 1316-1324. [CrossRef] [PubMed]

113. Liu, J.; Kumar, K.G.S.; Yu, D.; Molton, S.A.; McMahon, M.; Herlyn, M.; Thomas-Tikhonenko, A.; Fuchs, S.Y. Oncogenic BRAF regulates $\beta$-Trcp expression and NF- $\mathrm{BB}$ activity in human melanoma cells. Oncogene 2007, 26, 1954-1958. [CrossRef] [PubMed]

114. Koch, A.; Waha, A.; Hartmann, W.; Hrychyk, A.; Schuller, U.; Waha, A.; Wharton, K.A., Jr.; Fuchs, S.Y.; von Schweinitz, D.; Pietsch, T. Elevated expression of Wnt antagonists is a common event in hepatoblastomas. Clin. Cancer. Res. 2005, 11, 4295-4304. [CrossRef] 
115. Kudo, Y.; Guardavaccaro, D.; Santamaria, P.G.; Koyama-Nasu, R.; Latres, E.; Bronson, R.; Yamasaki, L.; Pagano, M. Role of F-box protein $\beta$ Trcp1 in mammary gland development and tumorigenesis. Mol. Cell. Biol. 2004, 24, 8184-8194. [CrossRef]

116. Belaidouni, N.; Peuchmaur, M.; Perret, C.; Florentin, A.; Benarous, R.; Besnard-Guerin, C. Overexpression of human $\beta$ TrCP1 deleted of its $\mathrm{F}$ box induces tumorigenesis in transgenic mice. Oncogene 2005, 24, 2271-2276. [CrossRef]

117. Kim, S.; Jeong, S. Mutation hotspots in the $\beta$-Catenin gene: Lessons from the human cancer genome databases. Mol. Cells 2019, 42, 8-16.

118. Yaeger, R.; Chatila, W.K.; Lipsyc, M.D.; Hechtman, J.F.; Cercek, A.; Sanchez-Vega, F.; Jayakumaran, G.; Middha, S.; Zehir, A.; Donoghue, M.T.A.; et al. Clinical sequencing defines the genomic landscape of metastatic colorectal cancer. Cancer Cell 2018, 33, 125-136.e3. [CrossRef]

119. Minakuchi, M.; Kakazu, N.; Gorrin-Rivas, M.J.; Abe, T.; Copeland, T.D.; Ueda, K.; Adachi, Y. Identification and characterization of SEB, a novel protein that binds to the acute undifferentiated leukemia-associated protein SET. Eur. J. Biochem. 2001, 268, 1340-1351. [CrossRef]

120. Oakley, K.; Han, Y.; Vishwakarma, B.A.; Chu, S.; Bhatia, R.; Gudmundsson, K.O.; Keller, J.; Chen, X.; Vasko, V.; Jenkins, N.A.; et al. Setbp1 promotes the self-renewal of murine myeloid progenitors via activation of Hoxa9 and Hoxa10. Blood 2012, 119, 6099-6108. [CrossRef]

121. Nguyen, N.; Vishwakarma, B.A.; Oakley, K.; Han, Y.; Przychodzen, B.; Maciejewski, J.P.; Du, Y. Myb expression is critical for myeloid leukemia development induced by Setbp1 activation. Oncotarget 2016, 7, 86300-86312. [CrossRef] [PubMed]

122. Vishwakarma, B.A.; Nguyen, N.; Makishima, H.; Hosono, N.; Gudmundsson, K.O.; Negi, V.; Oakley, K.; Han, Y.; Przychodzen, B.; Maciejewski, J.P.; et al. Runx1 repression by histone deacetylation is critical for Setbp1-induced mouse myeloid leukemia development. Leukemia 2016, 30, 200-208. [CrossRef] [PubMed]

123. Piazza, R.; Valletta, S.; Winkelmann, N.; Redaelli, S.; Spinelli, R.; Pirola, A.; Antolini, L.; Mologni, L.; Donadoni, C.; Papaemmanuil, E.; et al. Recurrent SETBP1 mutations in atypical chronic myeloid leukemia. Nat. Genet. 2013, 45, 18-24. [CrossRef] [PubMed]

124. Makishima, H.; Yoshida, K.; Nguyen, N.; Przychodzen, B.; Sanada, M.; Okuno, Y.; Ng, K.P.; Gudmundsson, K.O.; Vishwakarma, B.A.; Jerez, A.; et al. Somatic SETBP1 mutations in myeloid malignancies. Nat. Genet. 2013, 45, 942-946. [CrossRef] [PubMed]

125. Sakaguchi, H.; Okuno, Y.; Muramatsu, H.; Yoshida, K.; Shiraishi, Y.; Takahashi, M.; Kon, A.; Sanada, M.; Chiba, K.; Tanaka, H.; et al. Exome sequencing identifies secondary mutations of SETBP1 and JAK3 in juvenile myelomonocytic leukemia. Nat. Genet. 2013, 45, 937-941. [CrossRef] [PubMed]

126. Blees, J.S.; Bokesch, H.R.; Rubsamen, D.; Schulz, K.; Milke, L.; Bajer, M.M.; Gustafson, K.R.; Henrich, C.J.; McMahon, J.B.; Colburn, N.H.; et al. Erioflorin stabilizes the tumor suppressor Pdcd4 by inhibiting its interaction with the E3-ligase $\beta$-TrCP1. PLoS ONE 2012, 7, e46567. [CrossRef] [PubMed]

127. Wei, S.; Lin, L.F.; Yang, C.C.; Wang, Y.C.; Chang, G.D.; Chen, H.; Chen, C.S. Thiazolidinediones modulate the expression of beta-catenin and other cell-cycle regulatory proteins by targeting the F-box proteins of Skp1-Cul1-F-box protein E3 ubiquitin ligase independently of peroxisome proliferator-activated receptor gamma. Mol. Pharmacol. 2007, 72, 725-733. [CrossRef]

128. Nakajima, H.; Fujiwara, H.; Furuichi, Y.; Tanaka, K.; Shimbara, N. A novel small-molecule inhibitor of NF- $\kappa B$ signaling. Biochem. Biophys. Res. Commun. 2008, 368, 1007-1013. [CrossRef]

129. Vashisht, A.A.; Zumbrennen, K.B.; Huang, X.; Powers, D.N.; Durazo, A.; Sun, D.; Bhaskaran, N.; Persson, A.; Uhlen, M.; Sangfelt, O.; et al. Control of iron homeostasis by an iron-regulated ubiquitin ligase. Science 2009, 326, 718-721. [CrossRef]

130. Salahudeen, A.A.; Thompson, J.W.; Ruiz, J.C.; Ma, H.W.; Kinch, L.N.; Li, Q.; Grishin, N.V.; Bruick, R.K. An E3 ligase possessing an iron-responsive hemerythrin domain is a regulator of iron homeostasis. Science 2009, 326, 722-726. [CrossRef]

131. Chollangi, S.; Thompson, J.W.; Ruiz, J.C.; Gardner, K.H.; Bruick, R.K. Hemerythrin-like domain within F-box and leucine-rich repeat protein 5 (FBXL5) communicates cellular iron and oxygen availability by distinct mechanisms. J. Biol. Chem. 2012, 287, 23710-23717. [CrossRef]

132. Zhang, N.; Liu, J.; Ding, X.; Aikhionbare, F.; Jin, C.; Yao, X. FBXL5 interacts with p150 Glued and regulates its ubiquitination. Biochem. Biophys. Res. Commun. 2007, 359, 34-39. [CrossRef] [PubMed] 
133. Vinas-Castells, R.; Frias, A.; Robles-Lanuza, E.; Zhang, K.; Longmore, G.D.; de Herreros, A.G.; Diaz, V.M. Nuclear ubiquitination by FBXL5 modulates Snail1 DNA binding and stability. Nucleic Acids Res. 2014, 42, 1079-1094. [CrossRef] [PubMed]

134. Chen, Z.W.; Liu, B.; Tang, N.W.; Xu, Y.H.; Ye, X.Y.; Li, Z.M.; Niu, X.M.; Shen, S.P.; Lu, S.; Xu, L. FBXL5-mediated degradation of single-stranded DNA-binding protein hSSB1 controls DNA damage response. Nucleic Acids Res. 2014, 42, 11560-11569. [CrossRef] [PubMed]

135. Machado-Oliveira, G.; Guerreiro, E.; Matias, A.C.; Facucho-Oliveira, J.; Pacheco-Leyva, I.; Braganca, J. FBXL5 modulates HIF-1 $\alpha$ transcriptional activity by degradation of CITED2. Arch. Biochem. Biophys. 2015, 576, 61-72. [CrossRef]

136. Moroishi, T.; Nishiyama, M.; Takeda, Y.; Iwai, K.; Nakayama, K.I. The FBXL5-IRP2 axis is integral to control of iron metabolism in vivo. Cell Metab. 2011, 14, 339-351. [CrossRef]

137. Muto, Y.; Nishiyama, M.; Nita, A.; Moroishi, T.; Nakayama, K.I. Essential role of FBXL5-mediated cellular iron homeostasis in maintenance of hematopoietic stem cells. Nat. Commun. 2017, 8, 16114. [CrossRef]

138. Muto, Y.; Moroishi, T.; Ichihara, K.; Nishiyama, M.; Shimizu, H.; Eguchi, H.; Moriya, K.; Koike, K.; Mimori, K.; Mori, M.; et al. Disruption of FBXL5-mediated cellular iron homeostasis promotes liver carcinogenesis. J. Exp. Med. 2019, 216, 950-965. [CrossRef]

139. Nanba, S.; Ikeda, F.; Baba, N.; Takaguchi, K.; Senoh, T.; Nagano, T.; Seki, H.; Takeuchi, Y.; Moritou, Y.; Yasunaka, T.; et al. Association of hepatic oxidative stress and iron dysregulation with HCC development after interferon therapy in chronic hepatitis C. J. Clin. Pathol. 2016, 69, 226-233. [CrossRef]

140. Wu, W.; Ding, H.; Cao, J.; Zhang, W. FBXL5 inhibits metastasis of gastric cancer through suppressing Snail1. Cell. Physiol. Biochem. 2015, 35, 1764-1772. [CrossRef]

141. Wu, W.D.; Wang, M.; Ding, H.H.; Qiu, Z.J. FBXL5 attenuates RhoGDI2-induced cisplatin resistance in gastric cancer cells. Eur. Rev. Med. Pharmacol. Sci. 2016, 20, 2551-2557. [PubMed]

142. Yao, H.; Su, S.; Xia, D.; Wang, M.; Li, Z.; Chen, W.; Ren, L.; Xu, L. F-box and leucine-rich repeat protein 5 promotes colon cancer progression by modulating PTEN/PI3K/AKT signaling pathway. Biomed. Pharmacother. 2018, 107, 1712-1719. [CrossRef] [PubMed]

143. Ahmed, M.; Jinks, N.; Babaei-Jadidi, R.; Kashfi, H.; Castellanos-Uribe, M.; May, S.T.; Mukherjee, A.; Nateri, A.S. Repurposing Antibacterial AM404 as a Potential Anticancer Drug for Targeting Colorectal Cancer Stem-Like Cells. Cancers 2019, 12, 106. [CrossRef] [PubMed]

144. Hemann, M.T.; Bric, A.; Teruya-Feldstein, J.; Herbst, A.; Nilsson, J.A.; Cordon-Cardo, C.; Cleveland, J.L.; Tansey, W.P.; Lowe, S.W. Evasion of the p53 tumour surveillance network by tumour-derived MYC mutants. Nature 2005, 436, 807-811. [CrossRef]

145. Wang, X.; Cunningham, M.; Zhang, X.; Tokarz, S.; Laraway, B.; Troxell, M.; Sears, R.C. Phosphorylation regulates c-Myc's oncogenic activity in the mammary gland. Cancer Res. 2011, 71, 925-936. [CrossRef]

146. Onoyama, I.; Tsunematsu, R.; Matsumoto, A.; Kimura, T.; de Alboran, I.M.; Nakayama, K.; Nakayama, K.I. Conditional inactivation of Fbxw7 impairs cell-cycle exit during $\mathrm{T}$ cell differentiation and results in lymphomatogenesis. J. Exp. Med. 2007, 204, 2875-2888. [CrossRef]

147. Matsuoka, S.; Oike, Y.; Onoyama, I.; Iwama, A.; Arai, F.; Takubo, K.; Mashimo, Y.; Oguro, H.; Nitta, E.; Ito, K.; et al. Fbxw7 acts as a critical fail-safe against premature loss of hematopoietic stem cells and development of T-ALL. Genes Dev. 2008, 22, 986-991. [CrossRef]

148. Thompson, B.J.; Jankovic, V.; Gao, J.; Buonamici, S.; Vest, A.; Lee, J.M.; Zavadil, J.; Nimer, S.D.; Aifantis, I. Control of hematopoietic stem cell quiescence by the E3 ubiquitin ligase Fbw7. J. Exp. Med. 2008, 205, 1395-1408. [CrossRef]

149. Reavie, L.; Gatta, G.D.; Crusio, K.; Aranda-Orgilles, B.; Buckley, S.M.; Thompson, B.; Lee, E.; Gao, J.; Bredemeyer, A.L.; Helmink, B.A.; et al. Regulation of hematopoietic stem cell differentiation by a single ubiquitin ligase-substrate complex. Nat. Immunol. 2010, 11, 207-215. [CrossRef]

150. Iriuchishima, H.; Takubo, K.; Matsuoka, S.; Onoyama, I.; Nakayama, K.I.; Nojima, Y.; Suda, T. Ex vivo maintenance of hematopoietic stem cells by quiescence induction through Fbxw7 $\alpha$ overexpression. Blood 2011, 117, 2373-2377. [CrossRef]

151. Ishikawa, Y.; Hosogane, M.; Okuyama, R.; Aoyama, S.; Onoyama, I.; Nakayama, K.I.; Nakayama, K. Opposing functions of Fbxw7 in keratinocyte growth, differentiation and skin tumorigenesis mediated through negative regulation of c-Myc and Notch. Oncogene 2013, 32, 1921-1932. [CrossRef] [PubMed] 
152. Takeishi, S.; Matsumoto, A.; Onoyama, I.; Naka, K.; Hirao, A.; Nakayama, K.I. Ablation of Fbxw7 eliminates leukemia-initiating cells by preventing quiescence. Cancer Cell 2013, 23, 347-361. [CrossRef] [PubMed]

153. Reavie, L.; Buckley, S.M.; Loizou, E.; Takeishi, S.; Aranda-Orgilles, B.; Ndiaye-Lobry, D.; Abdel-Wahab, O.; Ibrahim, S.; Nakayama, K.I.; Aifantis, I. Regulation of c-Myc ubiquitination controls chronic myelogenous leukemia initiation and progression. Cancer Cell 2013, 23, 362-375. [CrossRef] [PubMed]

154. Huber, A.L.; Papp, S.J.; Chan, A.B.; Henriksson, E.; Jordan, S.D.; Kriebs, A.; Nguyen, M.; Wallace, M.; Li, Z.; Metallo, C.M.; et al. CRY2 and FBXL3 cooperatively degrade c-MYC. Mol. Cell 2016, 64, 774-789. [CrossRef]

155. Busino, L.; Bassermann, F.; Maiolica, A.; Lee, C.; Nolan, P.M.; Godinho, S.I.; Draetta, G.F.; Pagano, M. SCFFbxl3 controls the oscillation of the circadian clock by directing the degradation of cryptochrome proteins. Science 2007, 316, 900-904. [CrossRef]

156. Godinho, S.I.; Maywood, E.S.; Shaw, L.; Tucci, V.; Barnard, A.R.; Busino, L.; Pagano, M.; Kendall, R.; Quwailid, M.M.; Romero, M.R.; et al. The after-hours mutant reveals a role for Fbxl3 in determining mammalian circadian period. Science 2007, 316, 897-900. [CrossRef]

157. Siepka, S.M.; Yoo, S.H.; Park, J.; Song, W.; Kumar, V.; Hu, Y.; Lee, C.; Takahashi, J.S. Circadian mutant Overtime reveals F-box protein FBXL3 regulation of cryptochrome and period gene expression. Cell 2007, 129, 1011-1023. [CrossRef]

158. Fang, X.; Zhou, W.; Wu, Q.; Huang, Z.; Shi, Y.; Yang, K.; Chen, C.; Xie, Q.; Mack, S.C.; Wang, X.; et al. Deubiquitinase USP13 maintains glioblastoma stem cells by antagonizing FBXL14-mediated Myc ubiquitination. J. Exp. Med. 2017, 214, 245-267. [CrossRef]

159. Mei, Z.; Zhang, D.; Hu, B.; Wang, J.; Shen, X.; Xiao, W. FBXO32 targets c-Myc for proteasomal degradation and inhibits c-Myc activity. J. Biol. Chem. 2015, 290, 16202-16214. [CrossRef]

160. Cepeda, D.; Ng, H.F.; Sharifi, H.R.; Mahmoudi, S.; Cerrato, V.S.; Fredlund, E.; Magnusson, K.; Nilsson, H.; Malyukova, A.; Rantala, J.; et al. CDK-mediated activation of the $\mathrm{SCF}^{\mathrm{FBXO} 28}$ ubiquitin ligase promotes MYC-driven transcription and tumourigenesis and predicts poor survival in breast cancer. EMBO Mol. Med. 2013, 5, 1067-1086. [CrossRef]

161. Kim, S.Y.; Herbst, A.; Tworkowski, K.A.; Salghetti, S.E.; Tansey, W.P. Skp2 regulates Myc protein stability and activity. Mol. Cell 2003,11,1177-1188. [CrossRef]

162. von der Lehr, N.; Johansson, S.; Wu, S.; Bahram, F.; Castell, A.; Cetinkaya, C.; Hydbring, P.; Weidung, I.; Nakayama, K.; Nakayama, K.I.; et al. The F-box protein Skp2 participates in c-Myc proteosomal degradation and acts as a cofactor for c-Myc-regulated transcription. Mol. Cell 2003, 11, 1189-1200. [CrossRef]

163. Chan, C.H.; Lee, S.W.; Li, C.F.; Wang, J.; Yang, W.L.; Wu, C.Y.; Wu, J.; Nakayama, K.I.; Kang, H.Y.; Huang, H.Y.; et al. Deciphering the transcriptional complex critical for RhoA gene expression and cancer metastasis. Nat. Cell Biol. 2010, 12, 457-467. [CrossRef] [PubMed]

164. Li, X.; Bian, Y.; Takizawa, Y.; Hashimoto, T.; Ikoma, T.; Tanaka, J.; Kitamura, N.; Inagaki, Y.; Komada, M.; Tanaka, T. ERK-dependent downregulation of Skp2 reduces Myc activity with HGF, leading to inhibition of cell proliferation through a decrease in Id1 expression. Mol. Cancer Res. 2013, 11, 1437-1447. [CrossRef] [PubMed]

165. Popov, N.; Schulein, C.; Jaenicke, L.A.; Eilers, M. Ubiquitylation of the amino terminus of Myc by SCF ${ }^{\beta-T r C P}$ antagonizes SCF ${ }^{\mathrm{Fbw} 7}$-mediated turnover. Nat. Cell Biol. 2010, 12, 973-981. [CrossRef] [PubMed]

166. Chen, Y.; Sun, X.X.; Sears, R.C.; Dai, M.S. Writing and erasing MYC ubiquitination and SUMOylation. Genes Dis. 2019, 6, 359-371. [CrossRef]

167. Xiong, Y.; Connolly, T.; Futcher, B.; Beach, D. Human D-type cyclin. Cell 1991, 65, 691-699. [CrossRef]

168. Kato, J.Y.; Sherr, C.J. Inhibition of granulocyte differentiation by G1 cyclins D2 and D3 but not D1. Proc. Natl. Acad. Sci. USA 1993, 90, 11513-11517. [CrossRef]

169. Coleman, M.L.; Marshall, C.J. A family outing: Small GTPases cyclin' through G1. Nat. Cell Biol. 2001, 3, E250-E251. [CrossRef]

170. Qie, S.; Diehl, J.A. Cyclin D degradation by E3 ligases in cancer progression and treatment. Semin. Cancer Biol. 2020. [CrossRef]

171. Diehl, J.A.; Cheng, M.; Roussel, M.F.; Sherr, C.J. Glycogen synthase kinase- $3 \beta$ regulates cyclin D1 proteolysis and subcellular localization. Genes Dev. 1998, 12, 3499-3511. [CrossRef]

172. Barbash, O.; Zamfirova, P.; Lin, D.I.; Chen, X.; Yang, K.; Nakagawa, H.; Lu, F.; Rustgi, A.K.; Diehl, J.A. Mutations in $\mathrm{Fbx} 4$ inhibit dimerization of the $\mathrm{SCF}^{\mathrm{Fbx} 4}$ ligase and contribute to cyclin D1 overexpression in human cancer. Cancer Cell 2008, 14, 68-78. [CrossRef] 
173. Diehl, J.A.; Zindy, F.; Sherr, C.J. Inhibition of cyclin D1 phosphorylation on threonine-286 prevents its rapid degradation via the ubiquitin-proteasome pathway. Genes Dev. 1997, 11, 957-972. [CrossRef]

174. Benzeno, S.; Lu, F.; Guo, M.; Barbash, O.; Zhang, F.; Herman, J.G.; Klein, P.S.; Rustgi, A.; Diehl, J.A. Identification of mutations that disrupt phosphorylation-dependent nuclear export of cyclin D1. Oncogene 2006, 25, 6291-6303. [CrossRef] [PubMed]

175. Lin, D.I.; Barbash, O.; Kumar, K.G.; Weber, J.D.; Harper, J.W.; Klein-Szanto, A.J.; Rustgi, A.; Fuchs, S.Y.; Diehl, J.A. Phosphorylation-dependent ubiquitination of cyclin D1 by the $\mathrm{SCF}^{\mathrm{FBX} 4-\alpha \mathrm{B} \text { crystallin }}$ complex. Mol. Cell 2006, 24, 355-366. [CrossRef]

176. Vaites, L.P.; Lee, E.K.; Lian, Z.; Barbash, O.; Roy, D.; Wasik, M.; Klein-Szanto, A.J.; Rustgi, A.K.; Diehl, J.A. The Fbx4 tumor suppressor regulates cyclin D1 accumulation and prevents neoplastic transformation. Mol. Cell. Biol. 2011, 31, 4513-4523. [CrossRef] [PubMed]

177. Lian, Z.; Lee, E.K.; Bass, A.J.; Wong, K.K.; Klein-Szanto, A.J.; Rustgi, A.K.; Diehl, J.A. FBXO4 loss facilitates carcinogen induced papilloma development in mice. Cancer Biol. Ther. 2015, 16, 750-755. [CrossRef]

178. Lee, E.K.; Lian, Z.; D'Andrea, K.; Letrero, R.; Sheng, W.; Liu, S.; Diehl, J.N.; Pytel, D.; Barbash, O.; Schuchter, L.; et al. The FBXO4 tumor suppressor functions as a barrier to BRAF ${ }^{\mathrm{V} 600 \mathrm{E}}$-dependent metastatic melanoma. Mol. Cell. Biol. 2013, 33, 4422-4433. [CrossRef]

179. Santra, M.K.; Wajapeyee, N.; Green, M.R. F-box protein FBXO31 mediates cyclin D1 degradation to induce G1 arrest after DNA damage. Nature 2009, 459, 722-725. [CrossRef] [PubMed]

180. Li, Y.; Jin, K.; Bunker, E.; Zhang, X.; Luo, X.; Liu, X.; Hao, B. Structural basis of the phosphorylation-independent recognition of cyclin D1 by the $\mathrm{SCF}^{\mathrm{FBXO} 31}$ ubiquitin ligase. Proc. Natl. Acad. Sci. USA 2018, 115, 319-324. [CrossRef]

181. Wei, S.; Yang, H.C.; Chuang, H.C.; Yang, J.; Kulp, S.K.; Lu, P.J.; Lai, M.D.; Chen, C.S. A novel mechanism by which thiazolidinediones facilitate the proteasomal degradation of cyclin D1 in cancer cells. J. Biol. Chem. 2008, 283, 26759-26770. [CrossRef] [PubMed]

182. Okabe, H.; Lee, S.H.; Phuchareon, J.; Albertson, D.G.; McCormick, F.; Tetsu, O. A critical role for FBXW8 and MAPK in cyclin D1 degradation and cancer cell proliferation. PLoS ONE 2006, 1, e128. [CrossRef] [PubMed]

183. Pawar, S.A.; Sarkar, T.R.; Balamurugan, K.; Sharan, S.; Wang, J.; Zhang, Y.; Dowdy, S.F.; Huang, A.M.; Sterneck, E. C/EBP $\delta$ targets cyclin D1 for proteasome-mediated degradation via induction of CDC27/APC3 expression. Proc. Natl. Acad. Sci. USA 2010, 107, 9210-9215. [CrossRef] [PubMed]

184. Kanie, T.; Onoyama, I.; Matsumoto, A.; Yamada, M.; Nakatsumi, H.; Tateishi, Y.; Yamamura, S.; Tsunematsu, R.; Matsumoto, M.; Nakayama, K.I. Genetic reevaluation of the role of F-box proteins in cyclin D1 degradation. Mol. Cell. Biol. 2012, 32, 590-605. [CrossRef] [PubMed]

185. Grau, Y.; Carteret, C.; Simpson, P. Mutations and chromosomal rearrangements affecting the expression of Snail, a gene involved in embryonic patterning in DROSOPHILA MELANOGASTER. Genetics 1984, 108, 347-360.

186. Alberga, A.; Boulay, J.L.; Kempe, E.; Dennefeld, C.; Haenlin, M. The snail gene required for mesoderm formation in Drosophila is expressed dynamically in derivatives of all three germ layers. Development 1991, 111, 983-992.

187. Nieto, M.A. The snail superfamily of zinc-finger transcription factors. Nat. Rev. Mol. Cell Biol. 2002, 3, 155-166. [CrossRef] [PubMed]

188. Peinado, H.; Ballestar, E.; Esteller, M.; Cano, A. Snail mediates E-cadherin repression by the recruitment of the Sin3A/histone deacetylase 1 (HDAC1)/HDAC2 complex. Mol. Cell. Biol. 2004, 24, 306-319. [CrossRef]

189. Peinado, H.; Olmeda, D.; Cano, A. Snail, Zeb and bHLH factors in tumour progression: An alliance against the epithelial phenotype? Nat. Rev. Cancer 2007, 7, 415-428. [CrossRef]

190. Dominguez, D.; Montserrat-Sentis, B.; Virgos-Soler, A.; Guaita, S.; Grueso, J.; Porta, M.; Puig, I.; Baulida, J.; Franci, C.; de Herreros, A.G. Phosphorylation regulates the subcellular location and activity of the snail transcriptional repressor. Mol. Cell. Biol. 2003, 23, 5078-5089. [CrossRef]

191. Zou, S.; Ma, C.; Yang, F.; Xu, X.; Jia, J.; Liu, Z. FBXO31 suppresses gastric cancer EMT by targeting Snail1 for proteasomal degradation. Mol. Cancer Res. 2018, 16, 286-295. [CrossRef] [PubMed]

192. Sun, R.; Xie, H.Y.; Qian, J.X.; Huang, Y.N.; Yang, F.; Zhang, F.L.; Shao, Z.M.; Li, D.Q. FBXO22 possesses both protumorigenic and antimetastatic roles in breast cancer progression. Cancer Res. 2018, 78, 5274-5286. [CrossRef] [PubMed] 
193. Zhang, K.; Rodriguez-Aznar, E.; Yabuta, N.; Owen, R.J.; Mingot, J.M.; Nojima, H.; Nieto, M.A.; Longmore, G.D. Lats2 kinase potentiates Snail1 activity by promoting nuclear retention upon phosphorylation. EMBO J. 2012, 31, 29-43. [CrossRef] [PubMed]

194. Yang, Z.; Rayala, S.; Nguyen, D.; Vadlamudi, R.K.; Chen, S.; Kumar, R. Pak1 phosphorylation of snail, a master regulator of epithelial-to-mesenchyme transition, modulates snail's subcellular localization and functions. Cancer Res. 2005, 65, 3179-3184. [CrossRef]

195. Zhang, K.; Corsa, C.A.; Ponik, S.M.; Prior, J.L.; Piwnica-Worms, D.; Eliceiri, K.W.; Keely, P.J.; Longmore, G.D. The collagen receptor discoidin domain receptor 2 stabilizes SNAIL1 to facilitate breast cancer metastasis. Nat. Cell Biol. 2013, 15, 677-687. [CrossRef]

196. Park, S.Y.; Kim, H.S.; Kim, N.H.; Ji, S.; Cha, S.Y.; Kang, J.G.; Ota, I.; Shimada, K.; Konishi, N.; Nam, H.W.; et al. Snail1 is stabilized by O-GlcNAc modification in hyperglycaemic condition. EMBO J. 2010, 29, 3787-3796. [CrossRef]

197. Vinas-Castells, R.; Beltran, M.; Valls, G.; Gomez, I.; Garcia, J.M.; Montserrat-Sentis, B.; Baulida, J.; Bonilla, F.; de Herreros, A.G.; Diaz, V.M. The hypoxia-controlled FBXL14 ubiquitin ligase targets SNAIL1 for proteasome degradation. J. Biol. Chem. 2010, 285, 3794-3805. [CrossRef]

198. Zhang, Y.; Zhang, X.; Ye, M.; Jing, P.; Xiong, J.; Han, Z.; Kong, J.; Li, M.; Lai, X.; Chang, N.; et al. FBW7 loss promotes epithelial-to-mesenchymal transition in non-small cell lung cancer through the stabilization of Snail protein. Cancer Lett. 2018, 419, 75-83. [CrossRef]

199. Xiao, G.; Li, Y.; Wang, M.; Li, X.; Qin, S.; Sun, X.; Liang, R.; Zhang, B.; Du, N.; Xu, C.; et al. FBXW7 suppresses epithelial-mesenchymal transition and chemo-resistance of non-small-cell lung cancer cells by targeting snai1 for ubiquitin-dependent degradation. Cell Prolif. 2018, 51, e12473. [CrossRef]

200. Zheng, H.; Shen, M.; Zha, Y.L.; Li, W.; Wei, Y.; Blanco, M.A.; Ren, G.; Zhou, T.; Storz, P.; Wang, H.Y.; et al. PKD1 phosphorylation-dependent degradation of SNAIL by SCF-FBXO11 regulates epithelial-mesenchymal transition and metastasis. Cancer Cell 2014, 26, 358-373. [CrossRef]

201. Jin, Y.; Shenoy, A.K.; Doernberg, S.; Chen, H.; Luo, H.; Shen, H.; Lin, T.; Tarrash, M.; Cai, Q.; Hu, X.; et al. FBXO11 promotes ubiquitination of the Snail family of transcription factors in cancer progression and epidermal development. Cancer Lett. 2015, 362, 70-82. [CrossRef] [PubMed]

202. Saiga, T.; Fukuda, T.; Matsumoto, M.; Tada, H.; Okano, H.J.; Okano, H.; Nakayama, K.I. Fbxo45 forms a novel ubiquitin ligase complex and is required for neuronal development. Mol. Cell. Biol. 2009, 29, 3529-3543. [CrossRef] [PubMed]

203. Xu, M.; Zhu, C.; Zhao, X.; Chen, C.; Zhang, H.; Yuan, H.; Deng, R.; Dou, J.; Wang, Y.; Huang, J.; et al. Atypical ubiquitin E3 ligase complex Skp1-Pam-Fbxo45 controls the core epithelial-to-mesenchymal transition-inducing transcription factors. Oncotarget 2015, 6, 979-994. [CrossRef] [PubMed]

204. Wu, Z.Q.; Li, X.Y.; Hu, C.Y.; Ford, M.; Kleer, C.G.; Weiss, S.J. Canonical Wnt signaling regulates Slug activity and links epithelial-mesenchymal transition with epigenetic Breast Cancer 1, Early Onset (BRCA1) repression. Proc. Natl. Acad. Sci. USA 2012, 109, 16654-16659. [CrossRef]

205. Lane, D.P.; Crawford, L.V. T antigen is bound to a host protein in SV40-transformed cells. Nature 1979, 278, 261-263. [CrossRef]

206. Linzer, D.I.; Levine, A.J. Characterization of a $54 \mathrm{~K}$ dalton cellular SV40 tumor antigen present in SV40-transformed cells and uninfected embryonal carcinoma cells. Cell 1979, 17, 43-52. [CrossRef]

207. Baker, S.J.; Fearon, E.R.; Nigro, J.M.; Hamilton, S.R.; Preisinger, A.C.; Jessup, J.M.; vanTuinen, P.; Ledbetter, D.H.; Barker, D.F.; Nakamura, Y.; et al. Chromosome 17 deletions and p53 gene mutations in colorectal carcinomas. Science 1989, 244, 217-221. [CrossRef]

208. Petitjean, A.; Achatz, M.I.; Borresen-Dale, A.L.; Hainaut, P.; Olivier, M. TP53 mutations in human cancers: Functional selection and impact on cancer prognosis and outcomes. Oncogene 2007, 26, 2157-2165. [CrossRef]

209. Stegh, A.H. Targeting the p53 signaling pathway in cancer therapy - the promises, challenges and perils. Expert Opin. Ther. Targets 2012, 16, 67-83. [CrossRef]

210. Hafner, A.; Bulyk, M.L.; Jambhekar, A.; Lahav, G. The multiple mechanisms that regulate p53 activity and cell fate. Nat. Rev. Mol. Cell Biol. 2019, 20, 199-210. [CrossRef]

211. Kussie, P.H.; Gorina, S.; Marechal, V.; Elenbaas, B.; Moreau, J.; Levine, A.J.; Pavletich, N.P. Structure of the MDM2 oncoprotein bound to the p53 tumor suppressor transactivation domain. Science 1996, 274, 948-953. [CrossRef] [PubMed] 
212. Haupt, Y.; Maya, R.; Kazaz, A.; Oren, M. Mdm2 promotes the rapid degradation of p53. Nature 1997, 387, 296-299. [CrossRef] [PubMed]

213. Leng, R.P.; Lin, Y.; Ma, W.; Wu, H.; Lemmers, B.; Chung, S.; Parant, J.M.; Lozano, G.; Hakem, R.; Benchimol, S. Pirh2, a p53-induced ubiquitin-protein ligase, promotes p53 degradation. Cell 2003, 112, 779-791. [CrossRef]

214. Allton, K.; Jain, A.K.; Herz, H.M.; Tsai, W.W.; Jung, S.Y.; Qin, J.; Bergmann, A.; Johnson, R.L.; Barton, M.C. Trim 24 targets endogenous p53 for degradation. Proc. Natl. Acad. Sci. USA 2009, 106, 11612-11616. [CrossRef]

215. Banks, D.; Wu, M.; Higa, L.A.; Gavrilova, N.; Quan, J.; Ye, T.; Kobayashi, R.; Sun, H.; Zhang, H. L2DTL/CDT2 and PCNA interact with $\mathrm{p} 53$ and regulate $\mathrm{p} 53$ polyubiquitination and protein stability through MDM2 and CUL4A/DDB1 complexes. Cell Cycle 2006, 5, 1719-1729. [CrossRef]

216. Querido, E.; Blanchette, P.; Yan, Q.; Kamura, T.; Morrison, M.; Boivin, D.; Kaelin, W.G.; Conaway, R.C.; Conaway, J.W.; Branton, P.E. Degradation of p53 by adenovirus E4orf6 and E1B55K proteins occurs via a novel mechanism involving a Cullin-containing complex. Genes Dev. 2001, 15, 3104-3117. [CrossRef]

217. Wu, Z.Z.; Sun, N.K.; Chien, K.Y.; Chao, C.C. Silencing of the SNARE protein NAPA sensitizes cancer cells to cisplatin by inducing ERK1/2 signaling, synoviolin ubiquitination and p53 accumulation. Biochem. Pharmacol. 2011, 82, 1630-1640. [CrossRef]

218. Dornan, D.; Wertz, I.; Shimizu, H.; Arnott, D.; Frantz, G.D.; Dowd, P.; O’Rourke, K.; Koeppen, H.; Dixit, V.M. The ubiquitin ligase COP1 is a critical negative regulator of p53. Nature 2004, 429, 86-92. [CrossRef]

219. Yang, W.; Rozan, L.M.; McDonald, E.R., 3rd; Navaraj, A.; Liu, J.J.; Matthew, E.M.; Wang, W.; Dicker, D.T.; El-Deiry, W.S. CARPs are ubiquitin ligases that promote MDM2-independent p53 and phospho-p53ser20 degradation. J. Biol. Chem. 2007, 282, 3273-3281. [CrossRef]

220. Chen, D.; Kon, N.; Li, M.; Zhang, W.; Qin, J.; Gu, W. ARF-BP1/Mule is a critical mediator of the ARF tumor suppressor. Cell 2005, 121, 1071-1083. [CrossRef]

221. Zhong, Q.; Gao, W.; Du, F.; Wang, X. Mule/ARF-BP1, a BH3-only E3 ubiquitin ligase, catalyzes the polyubiquitination of Mcl-1 and regulates apoptosis. Cell 2005, 121, 1085-1095. [CrossRef] [PubMed]

222. Cheng, Q.; Cao, X.; Yuan, F.; Li, G.; Tong, T. Knockdown of WWP1 inhibits growth and induces apoptosis in hepatoma carcinoma cells through the activation of caspase 3 and p53. Biochem. Biophys. Res. Commun. 2014, 448, 248-254. [CrossRef] [PubMed]

223. Esser, C.; Scheffner, M.; Hohfeld, J. The chaperone-associated ubiquitin ligase CHIP is able to target p53 for proteasomal degradation. J. Biol. Chem. 2005, 280, 27443-27448. [CrossRef] [PubMed]

224. Muller, P.; Hrstka, R.; Coomber, D.; Lane, D.P.; Vojtesek, B. Chaperone-dependent stabilization and degradation of p53 mutants. Oncogene 2008, 27, 3371-3383. [CrossRef]

225. Zhang, X.; Li, C.F.; Zhang, L.; Wu, C.Y.; Han, L.; Jin, G.; Rezaeian, A.H.; Han, F.; Liu, C.; Xu, C.; et al. TRAF6 restricts p53 mitochondrial translocation, apoptosis, and tumor suppression. Mol. Cell 2016, 64, 803-814. [CrossRef]

226. Zhang, J.; Zhang, C.; Cui, J.; Ou, J.; Han, J.; Qin, Y.; Zhi, F.; Wang, R.F. TRIM45 functions as a tumor suppressor in the brain via its E3 ligase activity by stabilizing p53 through K63-linked ubiquitination. Cell Death Dis. 2017, 8, e2831. [CrossRef]

227. Yan, S.; Qiu, L.; Ma, K.; Zhang, X.; Zhao, Y.; Zhang, J.; Li, X.; Hao, X.; Li, Z. FATS is an E2-independent ubiquitin ligase that stabilizes p53 and promotes its activation in response to DNA damage. Oncogene 2014, 33, 5424-5433. [CrossRef]

228. Maan, M.; Pati, U. CHIP promotes autophagy-mediated degradation of aggregating mutant p53 in hypoxic conditions. FEBS J. 2018, 285, 3197-3214. [CrossRef]

229. Vrba, L.; Junk, D.J.; Novak, P.; Futscher, B.W. p53 induces distinct epigenetic states at its direct target promoters. BMC Genom. 2008, 9, 486. [CrossRef]

230. Johmura, Y.; Sun, J.; Kitagawa, K.; Nakanishi, K.; Kuno, T.; Naiki-Ito, A.; Sawada, Y.; Miyamoto, T.; Okabe, A.; Aburatani, H.; et al. SCF ${ }^{\mathrm{Fbxo} 22}$-KDM4A targets methylated p53 for degradation and regulates senescence. Nat. Commun. 2016, 7, 10574. [CrossRef]

231. Tan, M.K.; Lim, H.J.; Harper, J.W. SCF ${ }^{\mathrm{FBXO} 22}$ regulates histone H3 lysine 9 and 36 methylation levels by targeting histone demethylase KDM4A for ubiquitin-mediated proteasomal degradation. Mol. Cell. Biol. 2011, 31, 3687-3699. [CrossRef] [PubMed] 
232. Tian, X.; Dai, S.; Sun, J.; Jin, G.; Jiang, S.; Meng, F.; Li, Y.; Wu, D.; Jiang, Y. F-box protein FBXO22 mediates polyubiquitination and degradation of KLF4 to promote hepatocellular carcinoma progression. Oncotarget 2015, 6, 22767-22775. [CrossRef] [PubMed]

233. Zhu, X.N.; He, P.; Zhang, L.; Yang, S.; Zhang, H.L.; Zhu, D.; Liu, M.D.; Yu, Y. FBXO22 mediates polyubiquitination and inactivation of LKB1 to promote lung cancer cell growth. Cell Death Dis. 2019, 10, 486. [CrossRef] [PubMed]

234. Galindo-Moreno, M.; Giraldez, S.; Limon-Mortes, M.C.; Belmonte-Fernandez, A.; Reed, S.I.; Saez, C.; Japon, M.A.; Tortolero, M.; Romero, F. SCF ${ }^{\mathrm{FBXW7}}$-mediated degradation of p53 promotes cell recovery after UV-induced DNA damage. FASEB J. 2019, 33, 11420-11430. [CrossRef]

235. Cui, D.; Xiong, X.; Shu, J.; Dai, X.; Sun, Y.; Zhao, Y. FBXW7 confers radiation survival by targeting p53 for degradation. Cell Rep. 2020, 30, 497-509.e4. [CrossRef]

236. Slingerland, J.M.; Hengst, L.; Pan, C.H.; Alexander, D.; Stampfer, M.R.; Reed, S.I. A novel inhibitor of cyclin-Cdk activity detected in transforming growth factor $\beta$-arrested epithelial cells. Mol. Cell. Biol. 1994, 14, 3683-3694. [CrossRef]

237. Koff, A.; Ohtsuki, M.; Polyak, K.; Roberts, J.M.; Massague, J. Negative regulation of G1 in mammalian cells: Inhibition of cyclin E-dependent kinase by TGF- $\beta$. Science 1993, 260, 536-539. [CrossRef]

238. Polyak, K.; Kato, J.Y.; Solomon, M.J.; Sherr, C.J.; Massague, J.; Roberts, J.M.; Koff, A. p27Kip1 , a cyclin-Cdk inhibitor, links transforming growth factor-beta and contact inhibition to cell cycle arrest. Genes Dev. 1994, 8, 9-22. [CrossRef]

239. Hengst, L.; Dulic, V.; Slingerland, J.M.; Lees, E.; Reed, S.I. A cell cycle-regulated inhibitor of cyclin-dependent kinases. Proc. Natl. Acad. Sci. USA 1994, 91, 5291-5295. [CrossRef]

240. Besson, A.; Dowdy, S.F.; Roberts, J.M. CDK inhibitors: Cell cycle regulators and beyond. Dev. Cell 2008, 14, 159-169. [CrossRef]

241. Slingerland, J.; Pagano, M. Regulation of the cdk inhibitor p27 and its deregulation in cancer. J. Cell. Physiol. 2000, 183, 10-17. [CrossRef]

242. Hershko, D.D.; Shapira, M. Prognostic role of p27Kip1 deregulation in colorectal cancer. Cancer 2006, 107, 668-675. [CrossRef]

243. Ishihara, S.; Minato, K.; Hoshino, H.; Saito, R.; Hara, F.; Nakajima, T.; Mori, M. The cyclin-dependent kinase inhibitor $\mathrm{p} 27$ as a prognostic factor in advanced non-small cell lung cancer: Its immunohistochemical evaluation using biopsy specimens. Lung Cancer 1999, 26, 187-194. [CrossRef]

244. Wiksten, J.P.; Lundin, J.; Nordling, S.; Kokkola, A.; von Boguslawski, K.; Haglund, C. The prognostic value of p27 in gastric cancer. Oncology 2002, 63, 180-184. [CrossRef]

245. Ganoth, D.; Bornstein, G.; Ko, T.K.; Larsen, B.; Tyers, M.; Pagano, M.; Hershko, A. The cell-cycle regulatory protein $\mathrm{Cks} 1$ is required for $\mathrm{SCF}^{\mathrm{Skp} 2}$-mediated ubiquitinylation of p27. Nat. Cell Biol. 2001, 3, 321-324. [CrossRef]

246. Oshikawa, K.; Matsumoto, M.; Oyamada, K.; Nakayama, K.I. Proteome-wide identification of ubiquitylation sites by conjugation of engineered lysine-less ubiquitin. J. Proteome Res. 2012, 11, 796-807. [CrossRef]

247. Osoegawa, A.; Yoshino, I.; Tanaka, S.; Sugio, K.; Kameyama, T.; Yamaguchi, M.; Maehara, Y. Regulation of p27 by S-phase kinase-associated protein 2 is associated with aggressiveness in non-small-cell lung cancer. J. Clin. Oncol. 2004, 22, 4165-4173. [CrossRef]

248. Bochis, O.V.; Irimie, A.; Pichler, M.; Berindan-Neagoe, I. The role of Skp2 and its substrate CDKN1B (p27) in colorectal cancer. J. Gastrointestin. Liver Dis. 2015, 24, 225-234. [CrossRef]

249. Kamura, T.; Hara, T.; Matsumoto, M.; Ishida, N.; Okumura, F.; Hatakeyama, S.; Yoshida, M.; Nakayama, K.; Nakayama, K.I. Cytoplasmic ubiquitin ligase KPC regulates proteolysis of p27 ${ }^{\mathrm{Kip} 1}$ at G1 phase. Nat. Cell Biol. 2004, 6, 1229-1235. [CrossRef]

250. Hattori, T.; Isobe, T.; Abe, K.; Kikuchi, H.; Kitagawa, K.; Oda, T.; Uchida, C.; Kitagawa, M. Pirh2 promotes ubiquitin-dependent degradation of the cyclin-dependent kinase inhibitor p27 ${ }^{\mathrm{Kip} 1}$. Cancer Res. 2007, 67, 10789-10795. [CrossRef]

251. Zhao, B.; Yoganathan, K.; Li, L.; Lee, J.Y.; Zuniga-Pflucker, J.C.; Love, P.E. Notch and the pre-TCR coordinate thymocyte proliferation by induction of the SCF subunits Fbxl1 and Fbxl12. Nat. Immunol. 2019, 20, 1381-1392. [CrossRef] 
252. Rodriguez, S.; Abundis, C.; Boccalatte, F.; Mehrotra, P.; Chiang, M.Y.; Yui, M.A.; Wang, L.; Zhang, H.; Zollman, A.; Bonfim-Silva, R.; et al. Therapeutic targeting of the E3 ubiquitin ligase SKP2 in T-ALL. Leukemia 2020, 34, 1241-1252. [CrossRef]

253. Moi, P.; Chan, K.; Asunis, I.; Cao, A.; Kan, Y.W. Isolation of NF-E2-related factor 2 (Nrf2), a NF-E2-like basic leucine zipper transcriptional activator that binds to the tandem NF-E2/AP1 repeat of the beta-globin locus control region. Proc. Natl. Acad. Sci. USA 1994, 91, 9926-9930. [CrossRef]

254. Sporn, M.B.; Liby, K.T. NRF2 and cancer: The good, the bad and the importance of context. Nat. Rev. Cancer 2012, 12, 564-571. [CrossRef]

255. Ramos-Gomez, M.; Kwak, M.K.; Dolan, P.M.; Itoh, K.; Yamamoto, M.; Talalay, P.; Kensler, T.W. Sensitivity to carcinogenesis is increased and chemoprotective efficacy of enzyme inducers is lost in nrf2 transcription factor-deficient mice. Proc. Natl. Acad. Sci. USA 2001, 98, 3410-3415. [CrossRef]

256. Iida, K.; Itoh, K.; Kumagai, Y.; Oyasu, R.; Hattori, K.; Kawai, K.; Shimazui, T.; Akaza, H.; Yamamoto, M. Nrf2 is essential for the chemopreventive efficacy of oltipraz against urinary bladder carcinogenesis. Cancer Res. 2004, 64, 6424-6431. [CrossRef] [PubMed]

257. Kitamura, H.; Motohashi, H. NRF2 addiction in cancer cells. Cancer Sci. 2018, 109, 900-911. [CrossRef]

258. Rojo de la Vega, M.; Chapman, E.; Zhang, D.D. NRF2 and the hallmarks of cancer. Cancer Cell 2018, 34, $21-43$. [CrossRef]

259. Rada, P.; Rojo, A.I.; Chowdhry, S.; McMahon, M.; Hayes, J.D.; Cuadrado, A. SCF/ $\beta$-TrCP promotes glycogen synthase kinase 3-dependent degradation of the Nrf2 transcription factor in a Keap1-independent manner. Mol. Cell. Biol. 2011, 31, 1121-1133. [CrossRef]

260. Chowdhry, S.; Zhang, Y.; McMahon, M.; Sutherland, C.; Cuadrado, A.; Hayes, J.D. Nrf2 is controlled by two distinct $\beta$-TrCP recognition motifs in its Neh6 domain, one of which can be modulated by GSK-3 activity. Oncogene 2013, 32, 3765-3781. [CrossRef] [PubMed]

261. McMahon, M.; Thomas, N.; Itoh, K.; Yamamoto, M.; Hayes, J.D. Redox-regulated turnover of Nrf2 is determined by at least two separate protein domains, the redox-sensitive Neh2 degron and the redox-insensitive Neh6 degron. J. Biol. Chem. 2004, 279, 31556-31567. [CrossRef]

262. Lignitto, L.; LeBoeuf, S.E.; Homer, H.; Jiang, S.; Askenazi, M.; Karakousi, T.R.; Pass, H.I.; Bhutkar, A.J.; Tsirigos, A.; Ueberheide, B.; et al. Nrf2 activation promotes lung cancer metastasis by inhibiting the degradation of Bach1. Cell 2019, 178, 316-329.e18. [CrossRef] [PubMed]

263. Tan, M.K.; Lim, H.J.; Bennett, E.J.; Shi, Y.; Harper, J.W. Parallel SCF adaptor capture proteomics reveals a role for $\mathrm{SCF}^{\mathrm{FBXL17}}$ in NRF2 activation via BACH1 repressor turnover. Mol. Cell 2013, 52, 9-24. [CrossRef]

264. Zenke-Kawasaki, Y.; Dohi, Y.; Katoh, Y.; Ikura, T.; Ikura, M.; Asahara, T.; Tokunaga, F.; Iwai, K.; Igarashi, K. Heme induces ubiquitination and degradation of the transcription factor Bach1. Mol. Cell. Biol. 2007, 27, 6962-6971. [CrossRef] [PubMed]

265. Deng, L.; Meng, T.; Chen, L.; Wei, W.; Wang, P. The role of ubiquitination in tumorigenesis and targeted drug discovery. Signal. Transduct Target. Ther 2020, 5, 11. [CrossRef]

(C) 2020 by the authors. Licensee MDPI, Basel, Switzerland. This article is an open access article distributed under the terms and conditions of the Creative Commons Attribution (CC BY) license (http://creativecommons.org/licenses/by/4.0/). 